FEDERAL RESERVE BANK OF SAN FRANCISCO

WORKING PAPER SERIES

\title{
Scraping By: Income and Program Participation After the Loss of Extended Unemployment Benefits
}

\author{
Jesse Rothstein \\ Goldman School of Public Policy \& Department of Economics \\ University of California, Berkeley \\ Robert G. Valletta \\ Economic Research Department \\ Federal Reserve Bank of San Francisco
}

April 2017

Working Paper 2014-06

http://www.frbsf.org/economic-research/publications/working-papers/wp2014-06.pdf

Rothstein, Jesse, Robert G. Valletta. 2017. “Scraping By: Income and Program Participation After the Loss of Extended Unemployment Benefits” Federal Reserve Bank of San Francisco Working Paper 2014-06. http://www.frbsf.org/economicresearch/publications/working-papers/wp2014-06.pdf

The views in this paper are solely the responsibility of the authors and should not be interpreted as reflecting the views of the Federal Reserve Bank of San Francisco or the Board of Governors of the Federal Reserve System. 


\title{
Scraping By: Income and Program Participation After the Loss of Extended Unemployment Benefits
}

\author{
Jesse Rothstein \\ Goldman School of Public Policy \& Department of Economics \\ University of California, Berkeley \\ 2521 Channing Way \\ Berkeley, CA 94720-5555 USA \\ Phone: 1-510-495-0646 \\ E-mail: rothstein@berkeley.edu
}

Robert G. Valletta

Economic Research Department

Federal Reserve Bank of San Francisco

101 Market Street

San Francisco, CA 94105 USA

Phone: 1-415-974-3345

E-mail: rob.valletta@sf.frb.org

April 2017

* We thank Marianne Bitler, Julie Hotchkiss, and participants at the IZA/OECD/World Bank Conference on Safety Nets and Benefit Dependence (May 2013) and the All-California Labor Conference (September 2013) for comments, plus Jeongsoo Kim of the Census Bureau for SIPP data advice. We also thank Leila Bengali for outstanding research assistance. Rothstein thanks the Russell Sage Foundation for financial support. The views expressed in this paper are those of the authors and should not be attributed to anyone else at the Federal Reserve Bank of San Francisco or the Federal Reserve System. 


\title{
Scraping By: Income and Program Participation After the Loss of Extended Unemployment Benefits
}

\begin{abstract}
Many Unemployment Insurance (UI) recipients do not find new jobs before exhausting their benefits, even when benefits are extended during recessions. Using SIPP panel data covering the 2001 and 2007-09 recessions and their aftermaths, we identify individuals whose jobless spells outlasted their UI benefits (exhaustees) and examine household income, program participation, and health-related outcomes during the six months following UI exhaustion. For the average exhaustee, the loss of UI benefits is only slightly offset by increased participation in other safety net programs (e.g., food stamps), and family poverty rates rise substantially. Self-reported disability also rises following UI exhaustion. These patterns do not vary dramatically across the UI extension episodes, household demographic groups, or broad income level prior to job loss. The results highlight the unique, important role of UI in the U.S. social safety net.
\end{abstract}




\section{Scraping By: Income and Program Participation After the Loss of Extended Unemployment Benefits}

\section{Introduction}

Unemployment Insurance (UI) is designed to cushion the blow of job loss to family budgets by providing cash flow while a displaced worker looks for work. During economic expansions, most recipients are able to find work relatively quickly, and the disincentive effects of UI benefits on job search rise with the duration of potential benefits. Thus, in the United States, the maximum duration of normal UI benefits is 26 weeks or less, much lower than in many European countries.

These potential benefit durations typically are extended around recessions. During 20102012, maximum UI benefit durations reached an unprecedented 99 weeks in most states. Despite this prolonged UI availability, many recipients used up, or "exhausted," their maximum benefits before finding jobs. We examine the experiences of such UI exhaustees during the periods following the 2001 and 2007-09 recessions.

Given the limited second-tier safety net in the United States, the extra income provided by UI extensions is particularly important for families left without any clear means of support at times when there are few jobs to be had. Insofar as extended benefits help families to maintain consumption, they also may increase aggregate spending and thus play an automatic stabilizer role (Gruber 1997; U.S. CBO 2012).

In standard economic models of optimal unemployment insurance benefits (e.g., Chetty 2008), UI design trades off the economic benefits of the program, primarily increased consumption among recipients, against the economic costs, which take the form of government expense and reduced job search effort. In weak labor markets, it may take longer than 26 weeks 
for even a diligent job seeker to find new work, and the disincentive effects may be less important (e.g., Landais, Michaillat, and Saez 2016; Kroft and Notowidigdo 2016; Schmieder, von Wachter, and Bender 2012).

An extended empirical literature examines the effects of UI benefit durations on job search, including in the U.S. "Great Recession" of 2007-09 and its aftermath (e.g., Rothstein 2011; Farber and Valletta 2015; Farber, Rothstein, and Valletta 2015). But there is comparably little evidence available about the consumption smoothing effects of UI, at least in the U.S. (see Kolrud et al. 2016 on Sweden). A key parameter for optimal UI models is the decline in consumption when UI benefits end (Chetty 2006). Available evidence indicates that UI recipients have quite limited wealth holdings, suggesting that consumption will fall along with current income (Gruber 1997, 2001; Chetty 2008). But there has been limited research into the income available to UI recipients and exhaustees. Unless those who exhaust their benefits are able to transition quickly to other safety net programs (e.g., Temporary Assistance to Needy Families or the Supplemental Nutrition Assistance Program) or other family members are able to increase their labor supply, the end of UI benefits may dramatically reduce family incomes and thus consumption. The experience of exhaustees during times of weak economic conditions is of particular interest, as in every downturn policymakers confront the question of just how long to extend benefits. Despite their importance, extended UI exhaustees have been the subject of only limited past research (Needels, Corson, and Nicholson 2001; U.S. CBO 2004; U.S. GAO 2012). In this paper, we examine the household incomes, program participation, and health of UI exhaustees during the periods following the 2001 and 2007-09 recessions, using longitudinal data from the 2001 and 2008 panels of the Survey of Income and Program Participation (SIPP). In part because the latter recession was so severe, we are able to identify a large number of 
exhaustees in our sample. We examine how the various components of household income and safety net program participation, along with self-reported health and insurance recipiency, change during the six-month periods following job loss and UI benefit exhaustion.

Our motivation is twofold. First, we hope to shed light on the consequences of UI exhaustion for recipients and their families, focusing on measureable income components. Second, we seek to understand program interactions. Do other safety net programs, such as food stamps, cash welfare, or Social Security, or other sources of income, provide a cushion for families that have exhausted their UI benefits? Any such interactions have important implications for both the budgetary cost of UI extensions and the design of UI policy. We examine a broader range of outcomes than a recent body of research that focused on interactions between UI and disability insurance (DI) (Lindner 2011; Lindner and Nichols 2012; Rutledge 2012; Mueller, Rothstein, and von Wachter 2016; Inderbitzin, Staubli, and Zweimuller 2016). ${ }^{1}$

To preview, our analyses show that UI exhaustees, at least during the recessionary periods we examine, are broadly similar in observable characteristics to UI recipients who find jobs before exhausting their benefits, with the obvious exception that exhaustees experience longer unemployment durations. Because UI exhaustees' earnings account for nearly 60 percent of pre-separation household income, job loss and the eventual exhaustion of UI payments both substantially reduce family resources. UI benefits fill in about one-quarter of pre-separation household income until they are exhausted. Following exhaustion, while we find subsequent statistically significant increases in participation in public assistance programs such as food stamps (Supplemental Nutrition Assistance Program, or SNAP), the increase in total payments

\footnotetext{
${ }^{1}$ Much of this work relies on administrative data that ends before the Great Recession. Even with data covering the post-recession period, direct analysis of UI to DI transitions is complicated by the extensive time lags between initial DI application and eventual receipt (see e.g. Autor et al. 2011; Mueller, Rothstein, and von Wachter 2016).
} 
from these programs averages only around 2 percent of pre-separation household income, or less than one tenth of the lost UI income. Other sources of family income also are little changed. Thus, total family income falls by 13 percent, and the poverty rate rises by 13 percentage points. The overall change in poverty is from under 10 percent initially to about 20 percent following job loss and nearly one-third in the six months following loss of UI benefits.

UI exhaustion is also associated with increases in Medicaid enrollment and the prevalence of self-reported disability. In general, patterns are broadly similar between the 2001 and 2008 recessions and across demographic groups, though there are some exceptions - for example, older recipients are more likely to receive Social Security benefits following exhaustion.

Our findings shed new light on the experiences of the long-term unemployed and on the role that UI plays in the social safety net. We discuss these implications further in the concluding section, along with caveats and implications for future research.

\section{Regular and Extended UI in the United States}

UI benefits are available to individuals with sufficient recent work history who lose jobs other than for cause, typically due to a permanent or temporary layoff. In most states, UI benefits equal half of the claimant's pre-separation weekly wage, up to a weekly maximum. This maximum ranges from $\$ 235$ (Mississippi) to $\$ 979$ (Massachusetts, including a dependents' allowance). Nationally, average weekly benefits are around $\$ 300$. They are paid only to those who are available for and actively searching for work. ${ }^{2}$

\footnotetext{
${ }^{2}$ The job search rules vary across states and are inconsistently enforced. It is often sufficient for a claimant to self-report that he or she is actively searching. UI administrators in some states attempt to verify search effort by, e.g., suggesting that the claimant apply for a particular open position.
} 
Benefits are ordinarily available for 26 weeks, but benefit durations are often extended in periods of economic weakness. The federal Extended Benefits (EB) program, established in 1970, provides, at the state's option, 13 or 20 additional weeks of benefits tied to a state's unemployment rate. Congress often supplements EB with additional temporary extensions during national recessions, including the Temporary Extension of Unemployment Compensation (TEUC) program in 2002-4, and the Emergency Unemployment Compensation (EUC) program in 2008-13. ${ }^{3}$ Maximum benefit durations were as high as 72 weeks in 2003, and as high as 99 weeks in late 2009 through 2012. Earlier cycles saw similar responses, although the maximum available extension durations have risen over time

Panel A of Figure 1 shows the evolution of UI benefit durations over the last two business cycles. The black and gray solid lines, respectively, show the minimum and maximum durations of benefits across states, while the dashed line shows the mean, weighting states by the number of job losers in each state as measured in monthly Current Population Survey data. The maxima of 72 and 99 weeks in the early 2000s and 2009-12 are immediately evident. The figure also shows that mean durations of available UI benefits were slightly above 40 weeks for most of 2002 and 2003, fell to 26 weeks from 2004 through mid-2008, then rose rapidly, reaching nearly 99 weeks from late 2009 through early $2012 .{ }^{4}$ The average fell to around 64 weeks by late 2012 and stayed near that level through the end of 2013, when the EUC program expired and the average fell below 26 weeks. ${ }^{5}$

\footnotetext{
${ }^{3}$ For additional details regarding the prevalence, distribution across states, and labor market effects of EUC and EB, see Rothstein (2011), Farber and Valletta (2015), and Valletta (2014). See Whittaker (2008) and Whittaker and Isaacs (2012) for earlier benefit extensions, as well as for details of TEUC and EUC.

${ }^{4} 13$ weeks of EB benefits were available in Alaska in mid-2005 and in Louisiana in late 2005 and early 2006 (following Hurricane Katrina).

${ }^{5}$ Eight states cut their benefit durations below 26 weeks in 2011-2013.
} 
Panel B of Figure 1 shows the number of UI recipients, separately for regular state programs and for the extended and emergency programs. Both rose during each of the labor market downturns and fell afterward. However, the cycle is more dramatic for the extended/emergency programs: Regular program recipiency rose from under 3 million in 2007 to a peak of just over 6 million in 2009, then gradually returned to around 3 million by late 2013 . By contrast, EUC and EB caseloads rose from 0 in early 2008 to a peak just shy of 6 million in early 2010, falling back to under 2 million by late 2013. Bitler and Hoynes (2016) show that total UI expenditures nearly quintupled between 2007 and 2010. SNAP (Food Stamp) enrollment and expenditures also rose substantially during that period, though by less, while expenditures on the other key means-tested safety net program - Temporary Assistance to Needy Families - were largely flat.

The Department of Labor tracks the number of UI recipients who exhaust their last week of regular benefits (not including EUC and EB) each month. This rose from about 200 thousand prior to the Great Recession to nearly 800 thousand at its peak in 2009 , subsequently falling under 300 thousand by the end of 2013. In the earlier cycle, it peaked around 400-450 thousand in mid-2002. The pattern of final exhaustions from extended and emergency benefits over the business cycle is more complicated, due to opposing effects: Unemployment durations rise during downturns, but potential benefit durations rise as well. Mueller, Rothstein, and von Wachter (2016) used EUC and EB program data to estimate final exhaustions. They found that due to these opposing effects, exhaustion rates fell as benefits were extended during the recession and early recovery, then rose along with unemployment durations. 


\section{UI, Consumption, and Program Interactions}

\section{A. Optimal UI and consumption}

Economists model the optimal duration of unemployment insurance as one that balances the costs and benefits of additional weeks. The benefits derive from consumption smoothing: When the marginal utility of consumption among the unemployed is lower than that of the employed, social welfare can be improved by transferring additional resources from workers to job-seekers. This transfer is constrained, however, by the need to limit the disincentive ("moral hazard") effects on job search among the unemployed. The optimal unemployment benefit balances these two considerations (Baily 1978; Chetty 2008). The moral hazard effects of UI are well studied (Rothstein 2011; Farber and Valletta 2013; Farber, Rothstein, and Valletta 2015; Valletta 2014; Katz and Meyer 1990; Card and Levine 2000; and Card, Chetty, and Weber 2007).

Much less is known about the degree to which UI benefits are necessary to permit recipients to maintain their consumption during periods of unemployment, but the limited direct evidence suggests substantial effects. Gruber (2001) examined the wealth holdings of the unemployed. He found that the typical job loser in the 1984-92 SIPP panels had enough liquid assets to replace only 5.4 weeks of earnings, with the long-term unemployed having less than half as much wealth as the short-term unemployed. In other work, Gruber (1997) examined how the consumption spending of the unemployed varies with the generosity of UI benefits. His results indicate that more generous benefits are associated with higher levels of consumption during unemployment, suggesting that UI benefits substantially enhance consumption smoothing for recipients. ${ }^{6}$ Saporta-Eksten (2014) reports similar results using more recent data. Chetty

\footnotetext{
${ }^{6}$ Gruber (1997) examines food expenditures but is unable to examine a broader consumption basket or to distinguish reduced consumption from changes in home production (e.g., increased labor devoted to
} 
(2008) reinforced these findings by showing that many households receiving UI benefits are liquidity constrained. His estimates indicate that much of the increase in unemployment durations associated with more generous UI benefits reflects the relaxation of this liquidity constraint rather than moral hazard effects.

Even less is known about the financial situation or consumption behavior of individuals who have exhausted their UI benefits, a key parameter in optimal UI duration calculations. Gruber's (2001) analysis suggests that such individuals are quite unlikely to have substantial remaining assets upon which to draw. We are aware of one study that used the 2001 panel of the SIPP to investigate the characteristics of individuals who had exhausted their UI benefits in late 2001 and early 2002 (U.S. CBO 2004). ${ }^{7}$ Those who were still not employed as of three months after the end of their UI benefits had average monthly family incomes of $\$ 2,530$, about half of the pre-unemployment level. The vast majority $(\$ 1,970)$ of the post-UI income came from earnings of family members other than the exhaustee. Only 7 percent of UI exhaustees had Social Security income, while one in ten were receiving food stamps. Among all exhaustees, 36 percent were in poverty; the corresponding figure was 73 percent for those who did not have other earners in the family. Our study builds on this by focusing more closely on the period immediately before and after benefit exhaustion, enabling us to distinguish exhaustion effects from heterogeneity - exhaustees might have had high poverty rates even before exhaustion - and by bringing in data from the 2008 panel, which due to the Great Recession has many more UI exhaustees.

economical food preparation).

${ }^{7}$ See also Needels et al. (2001), U.S. GAO (2012). 


\section{B. UI exhaustion and alternative income support}

UI may serve as a substitute for other income transfer programs (e.g., food stamps, retirement benefits, disability insurance benefits, and cash welfare) by providing temporary income support during unemployment spells, thereby alleviating the need to participate in these other programs. Alternatively, UI may complement other programs, if UI disincentive effects reduce job-finding and recipients increase their use of other programs to supplement low UI benefits during their extended unemployment spells.

Again, little direct evidence on interactions between extended UI and other programs is available. Some recent research has examined interactions between UI and DI applications. Lindner and Nichols (2012) explored the effect of UI benefit generosity and eligibility criteria on DI applications. Rutledge (2012) and Mueller, Rothstein, and von Wachter (2016) examined the effect of UI exhaustion on DI application. Rutledge found that the presence of a UI extension is positively associated with DI applications among those who were claiming UI when the extension was announced. By contrast, Mueller et al. used UI extensions as a source of variation in the date of UI benefit exhaustion and uncovered no effect of impending or recent exhaustion on DI application. Using Austrian data, Inderbitzin, Staubli, and Zweimuller (2016) found evidence for both complementarity and substitution effects between extended UI benefits and retirement programs, with the substitution effects tending to dominate for the older worker groups in their data. We examine retirement (Social Security) income as part of our analyses.

\section{SIPP Nonemployment Spell Data}

Our analysis relies on panel data from the 2001 and 2008 panels of the Survey of Income and Program Participation (SIPP). The SIPP is a nationally representative sample of individuals 
and the households in which they reside. It was designed specifically to "provide accurate and comprehensive information about the income and program participation of individuals and households in the United States, and about the principal determinants of income and program participation." ${ }^{\prime 8}$ As such, it is well-suited for the analysis of receipt of UI and other types of income, changes over time, and related labor market outcomes. The SIPP is structured as a series of non-overlapping panels, with new panels beginning every three or four years and respondents to each panel interviewed every four months. Each interview collects income and related data at a monthly frequency and labor force status at the weekly level, covering the period since the prior interview. This permits direct measurement of employment transitions, unemployment durations, and program participation.

The 2001 SIPP panel consisted of 9 interview waves, covering October 2000 through January 2004. The 2008 panel had 16 waves, stretching from May 2008 through late 2013. ${ }^{9}$ These correspond closely with the periods of labor market weakness and UI benefit extensions associated with the 2001 and 2007-9 recessions.

\section{A. Sample construction: base sample, UI exhaustees}

Our goal is to examine individuals who have lost jobs, gone onto UI, and exhausted their benefits before becoming reemployed. However, we start with a broader sample of job separators, which we use for comparison purposes with UI exhaustees.

To construct our sample, we begin with individuals age 18 to 64 (at the time they enter the panel) who report job separations into unemployment at any time during the 2001 or 2008

\footnotetext{
${ }^{8}$ See the description at http://www.census.gov/sipp/intro.html.

${ }^{9}$ Because interviews for each wave are staggered across a four-month period, the complete number of calendar months covered by each panel is slightly larger than the number of waves multiplied by four.
} 
SIPP panels. ${ }^{10}$ We restrict attention to separations that follow jobs that lasted at least three months, as separations following short-term jobs are unlikely to result in new UI eligibility. Although the SIPP has only limited and inconsistent information about the reason for job separation, our primary analyses focus on individuals who received UI benefits during their nonemployment spells, ensuring that the corresponding separations largely reflect job losses rather than quits (which are generally ineligible for UI). Our spells start with unemployment (i.e., active job search), but we keep individuals in the sample as long as they remain jobless, as some respondents report UI recipiency despite also reporting that they are not active searchers (i.e., they self-identify as labor force non-participants).

Unfortunately, the SIPP data do not measure the duration of UI benefits for which a respondent is eligible. We thus cannot observe benefit exhaustion directly. We explored identifying exhaustees as those who received benefits continually from job loss to the maximum duration of available benefits in their state at the time. As discussed below, few UI recipients meet this definition of exhaustion, but a much larger number receive benefits for a time, then stop receiving them despite continued nonemployment.

We adopt a sample definition intended to identify exhaustees, including those who receive less than the maximum potential benefits in their states, while minimizing the number of non-exhaustees included. Beginning with our sample of job separators, we restrict attention to those who received UI during at least four months of the subsequent nonemployment spell. We then identify the end of the nonemployment spell, allowing for very short-term jobs: We count the nonemployment spell as ending in a week where the individual is employed, provided that he

\footnotetext{
${ }^{10}$ See Appendix A for additional details regarding sample construction and definitions.
} 
or she remains employed for at least four consecutive weeks. ${ }^{11} \mathrm{We}$ define an individual as an exhaustee if his or her nonemployment spell continued for at least one month beyond the last month in which UI benefits were received. ${ }^{12}$ We then track income and program participation from the date of UI exhaustion until the individual is reemployed or for six months, whichever is shorter. Our restriction to nonemployment spells that continue beyond the end of UI benefits is meant to exclude those who might have drawn more UI benefits but did not because they became reemployed.

Many of the SIPP respondents that we classify as UI exhaustees receive fewer months of UI benefits than appear to be available in their states at the relevant time. We are unable to distinguish whether these individuals were eligible for less than the maximum benefit duration (due, e.g., to insufficient earnings histories), whether their benefits were cut off, whether they voluntarily stopped claiming UI despite having the option to continue (e.g., to receive retirement benefits instead), or whether their UI benefit durations are misreported. Panel A of Figure 2 displays the distribution of months of UI receipt for UI exhaustees, while Panel B displays the distribution of the ratio of the number of months of benefits to the maximum number that should be available given state and federal law. ${ }^{13}$ In each case, we show results separately for the 2001

${ }^{11}$ This, like several of our other sample construction procedures, follows Cullen and Gruber (2000) and Chetty (2008). However, they focus on unemployment (rather than nonemployment) spells, which can end when an individual exits the labor force. The four-week requirement roughly corresponds to what would register as a flow into employment in the monthly Current Population Survey.

${ }^{12}$ Meyer, Mok, and Sullivan (2015) document under-reporting of UI and other program benefits in the SIPP. This may cause us to erroneously count as exhaustees respondents who report some but not all of their UI recipiency. Assuming this reporting error is random, it likely will cause an understatement of the impact of UI exhaustion on other outcomes.

${ }^{13}$ We measure the denominator by merging the SIPP data to a database of maximum UI durations by state and month constructed from Department of Labor "trigger notices," as described in Rothstein (2011) and Farber and Valletta (2015). This database yields durations in weeks; we divide by 4.33 (52/12) to obtain durations in months. The numerator is the number of calendar months in which benefits were received, which can legitimately exceed the number of full months of available benefits when spells start or end mid-month or recipients draw their UI benefits non-continuously. 
and 2008 panels, in recognition of the very different potential benefit durations in the two periods.

The ratio plot in Panel B shows that a substantial number of exhaustees have UI durations notably shorter than the statutory maximum available in their state (i.e., ratios well under one). In the 2008 panel, about 45 percent of our exhaustee sample receives fewer months of UI benefits than we calculate as their maximum eligibility. Nevertheless, there is clear evidence of a "hump" in the distribution around a ratio of one, corresponding to benefit durations equal to the statutory maximum. We opt to include the shorter durations in order to maximize the available sample size and also because it is likely that in many cases the shorter durations indeed reflect exhaustions (due to individual UI eligibility durations that are shorter than the state maximum) rather than reporting error. To minimize the influence of potential reporting error, however, we also discuss estimates below that restrict the sample to spells exceeding 75 percent of the apparent maximum. ${ }^{14}$

A well-known measurement issue in the SIPP and other panel surveys is "seam bias," or a tendency for changes in reported outcomes to concentrate in the first month covered by a new interview wave (see e.g. Moore 2007; Ham, Li, and Shore-Sheppard 2009). We see evidence of this in our measure of UI receipt: Roughly twice as many measured exhaustions occur in the last month of an interview wave as would be expected by chance. We take two steps to minimize the impact of seam bias. First, our analyses generally focus on averages over four or more months prior to or following exhaustion, so each period includes at least a full wave of data. Second, we have confirmed that our results are robust to excluding exhaustions occurring in the last month of

\footnotetext{
${ }^{14}$ The EUC program (as well as EB in many states) was temporarily suspended twice in 2010, though only briefly. We confirmed in our data that there is no noticeable uptick in measured UI exhaustion rates during the suspension months.
} 
a wave, or to reweighting the data so that the last month is not overrepresented in our exhaustee sample.

\section{B. Sample characteristics and descriptive statistics}

Table 1 displays detailed descriptive statistics for four subsamples of respondents who separate from a job and enter unemployment (as defined above) in the 2001 and 2008 SIPP panels. ${ }^{15}$ The first column includes our full sample of job separators with post-separation unemployment. This column includes over 36,000 separations, representing over 23,000 individuals. (Some individuals experience repeated separations.)

Column 2 limits the sample to nonemployment spells during which the respondent reports no receipt of UI benefits. Columns 3 and 4 limit to those with UI: In column 3, we include those who received UI in the last month before reemployment, while column 4 shows our exhaustee sample of long-term UI recipients whose nonemployment spells continued for at least one month beyond the end of their UI benefits. ${ }^{16}$ Only about one-quarter of those experiencing unemployment spells report receiving UI income, and in most of these cases it is received through the end of the nonemployment spell. Less than one-fifth of spells with UI income lead to exhaustions, by our definition. This corresponds to 1,721 UI exhaustions experienced by 1,299 unique individuals (implying that about one-quarter of exhaustees

\footnotetext{
${ }^{15}$ The SIPP sample includes both cross-sectional weights and longitudinal weights. Neither corresponds very well to our sample definitions. Our primary analyses therefore rely on unweighted estimates (though we present results using SIPP cross-sectional weights in Appendix Table B2). The descriptive statistics in Tables 1 and 2 are weighted using the SIPP cross-section weights corresponding to the final month of each nonemployment spell.

${ }^{16}$ Spells with short-term UI receipt followed by nonemployment without UI are represented in Column 1 but not in any of Columns 2-4.
} 
experience multiple exhaustions within a single SIPP panel). The weighted counts show that this corresponds to about 5.1 million individuals. ${ }^{17}$

Comparing the demographic characteristics across columns of Table 1, our exhaustees are generally similar in their demographic characteristics to non-exhausting UI recipients and to jobless individuals who do not receive UI. UI recipients are slightly older than non-recipients, and exhaustees older than non-exhaustees, but the differences are small. Distributions of educational attainment, race, and family structure are all quite similar across groups. ${ }^{18}$

Rows near the bottom of Table 1 show average earnings and household income (inflation adjusted) during the period 2-4 months prior to the beginning of the jobless spell. UI recipients have somewhat higher pre-separation earnings and household incomes than do those who do not receive UI, likely in part a reflection of the earnings history requirements for UI recipiency, but there is little difference between UI recipients who do and do not go on to exhaust their benefits. The next row of the table lists poverty rates averaged over the months of the nonemployment spell. Consistent with Census Bureau definitions, our poverty calculations are based on income including money transfers but not in-kind benefits (see Appendix A). Exhaustees have much higher poverty rates than do other UI recipients, while those who do not receive UI are intermediate between the two.

The final rows in Table 1 list household wealth figures (inflation adjusted), focusing on total net worth and liquid financial wealth; the latter excludes home equity, retirement funds, and other illiquid assets (see the table notes for exact definitions). These are merged from the SIPP

\footnotetext{
${ }^{17}$ Over 3 million of these are in the 2008 panel. A recent study from the U.S. GAO (2012), using data from the Displaced Workers Survey, identified about 2 million exhaustees from 2007 through early 2010. There were presumably more in the 2008-2013 window covered by the SIPP.

${ }^{18}$ Women and racial minorities are somewhat overrepresented among UI exhaustees versus UI recipients more generally. This is consistent with the finding from a study of UI exhaustion during the tight labor market of the late 1990s (Needels et al. 2001).
} 
topical modules on assets and liabilities, which are only available yearly (every third survey wave) and not at all after 2011. The observation counts listed show that we have pre-spell wealth data for a little over half of our sample of spells. We list median values because the means are heavily influenced by high values in the long tail of the distribution of household wealth. ${ }^{19}$

During the year leading up to job separation, the median household has net worth equal to about 5 to 6 months' worth of household income. However, most of this positive net worth consists of home equity. Thus, median liquid financial wealth is not far above zero and is only equal to about one-half of monthly household income. ${ }^{20}$ Eventual UI exhaustees have somewhat lower net worth and liquid wealth than do other UI recipients.

UI exhaustion would not be very interesting to study if few people remained jobless for long following the end of benefits. For example, past evidence indicates that some UI recipients delay reemployment until their benefits are exhausted (e.g., Katz and Meyer 1990; Rothstein 2011). For purposes of optimal UI policy, these recipients' post-exhaustion consumption patterns are of little interest. Appendix Figure B1 shows nonemployment and unemployment spell survival rates dated both from job loss (panel A) and from UI exhaustion (panel B). Over 50 percent of the 2001-04 exhaustees that we identify remain out of work three months after exhaustion, and 30 percent remain in that state after six months. These figures are significantly higher - roughly 65 percent and 50 percent, respectively - in the 2008 panel. Overall, reemployment hazards after UI exhaustion are quite similar to those in the early months of a

\footnotetext{
${ }^{19}$ The SIPP is known to understate wealth amounts relative to alternative sources such as the Survey of Consumer Finances (see for example Eggleston and Klee 2015). We use the SIPP wealth data for limited, illustrative purposes in our analyses, but we acknowledge that they may understate household financial assets and security to some degree.

${ }^{20}$ Unsecured debt (e.g., credit card debt) is subtracted to form net worth, but it is not used to adjust our liquid financial wealth variable. We discuss this further in our analysis of UI exhaustion (Section 6).
} 
jobless spell, and they indicate that a substantial fraction of individuals who exhaust their UI benefits remain jobless for an extended period.

The figures listed in Table 1 differ little between the 2001 and 2008 panels (not reported) ${ }^{21}$ But the number of job separations, the duration of nonemployment, and the number of exhaustions is much higher in the 2008 panel. Table 2 displays separate figures for the 2001 and 2008 SIPP panels, focusing on the substantial differences in the incidence and duration of nonemployment spells across the two panel periods. We identify roughly twice as many spells and more than twice as many UI recipients and exhaustees in the 2008 panel, reflecting the much worse labor market and large number of job losses in this period. Weighted tabulations indicate that our count of transitions from employment to unemployment is nearly 50 million in 2001-04 and nearly 100 million in $2008-13$. While these are very large numbers, they are readily reconciled with data on monthly gross labor force flows from the Current Population Survey (CPS). These data show an average of nearly 2 million monthly transitions from employment to unemployment during 2001-04 and about 2.2 million during 2008-13.22 Table 2 also shows that nonemployment spells are much longer for exhaustees than for non-exhaustees or for those who do not receive UI. Durations are longer for all groups in the 2008 panel, but particularly so for exhaustees, nearly half of whom are out of work for more than 99 weeks. This is unsurprising, given the dramatic benefit extensions during this period - someone who became reemployed relatively quickly would not have exhausted benefits during this period.

In our subsequent analyses and others not reported here, we find few meaningful differences between the 2001 and 2008 panels. We therefore pool the data from the two panels,

\footnotetext{
${ }^{21}$ One exception is average age, which is uniformly higher for all categories of job separators in 2008. The relative age of exhaustees, compared to non-exhaustees, does not differ between the two panels.

22 The CPS flows would imply even larger samples than we obtain, perhaps reflecting significant numbers of spurious transitions (https://www.bls.gov/webapps/legacy/cpsflowstab.htm).
} 
although we provide a comparison of results across them in Table 6 . We begin by examining changes in incomes following job loss, then turn to the period surrounding UI exhaustion.

\section{Income and Program Dynamics Surrounding Separation}

We lay the groundwork for our analysis of UI exhaustion by first examining outcomes before and after job loss. This serves the dual purpose of identifying the outcomes of interest and also providing a set of initial facts about the size of the "hole" in household budgets that UI benefits are intended to help fill.

Figure 3 displays the time pattern of total household income during the period leading up to and following an initial job loss, labeling the month in which the job was lost as 0 and the surrounding period by the time relative to that month. Income is measured as a share of its average level over the period 2-4 months before the job loss event. Estimates are shown for the full sample of UI recipients (including those who do not exhaust their benefits) and for our UI exhaustee sample. For the exhaustee sample, we show estimates for total household income and for income less UI benefits.

Among all UI recipients, household income falls by a bit less than 20 percent immediately following job loss. It then begins recovering immediately as some find new jobs. The exhaustee sample sees a larger decline, around 25 percent, that is more persistent. The decline reflects a nearly 50 percent decline in non-UI income, about half of which is offset by increases in UI. The larger decline in income and greater persistence in the exhaustee sample relative to the full UI recipient sample reflects the longer duration of unemployment spells among exhaustees, as many UI recipients become reemployed quite quickly and the income 
decline following job loss largely evaporates within six months. Among exhaustees, income does not recover meaningfully within the six-month window following job loss.

Table 3 summarizes household incomes and their composition during the three months prior to and the first six months of nonemployment after job loss, along with the difference between them. (For individuals who are reemployed within six months, only the months before reemployment are used to compute the post-separation mean.) The sample is restricted to eventual exhaustees. Bold text indicates a pre-post difference that is statistically significant at the 5 percent level.

The tabulations in Table 3 again show that household income drops nearly 25 percent on average (or about $\$ 1,500$ ) after job losses that lead to long-term unemployment spells and eventual UI exhaustion. The displaced worker's own earnings account for slightly more than half of household income prior to job loss in this sample of UI recipients, and fall to near zero after separation. ${ }^{23} \mathrm{UI}$ benefits replace about 40 percent of the lost earnings on average. These two factors account for nearly the entirety of household income changes observed after job loss.

Other income components show only small changes. Earnings of other household members increase a bit following job loss, making up about one-tenth of the displaced worker's lost earnings. The share of households with earnings from other members rises by about 8 percentage points, indicating that much of this is occurring on the extensive margin. Recipiency of SNAP (food stamps), Social Security, and other social welfare programs also increases after separation, though the amounts are small - increases in these programs make up only about 4 percent of the lost earnings.

\footnotetext{
${ }^{23}$ Results from Couch and Placzek (2010) indicate that job displacement is associated with substantial long-term earnings losses for UI recipients. This finding likely applies with particular force to our sample of exhaustees, given their protracted jobless spells.
} 
The last row of the table shows the expected large and statistically significant increases in poverty rates following job loss. The poverty rates in our sample rise from about 8 percentlower than the 13-15 percent average for the general population during our sample frame - to 22 percent.

\section{Income and Program Dynamics Surrounding UI Benefit Exhaustion}

We now turn to our examination of outcomes for the period surrounding exhaustion of UI benefits. We focus first on the complete sample of exhaustees and then turn to selected subsamples

\section{A. Results for the complete UI exhaustion sample}

Figure 4 (panels A and B) shows average total household incomes over this period, as before measuring them as a share of pre-separation income. Here, month 0 corresponds to the final month in which UI income was received, and month 1 to the first month without UI income. Recall that our exhaustee sample is limited to individuals who do not begin an employment spell lasting four weeks or more in the month following UI receipt. A consequence of this definition is that earnings cannot make up for lost UI income in month 1 , though they can in months 2 and thereafter. Thus, we show two sets of estimates. Panel A presents a series for all of our exhaustees, whether or not they have returned to work, along with a comparison group of all spells with UI income, including those who transit directly from UI to work. Panel B presents three series that restrict attention to those whose nonemployment spells extend for varying lengths beyond the end of UI. The dashed line shows estimates for those who remain out of work for at least three months after leaving UI, while the grey line shows those who remain out of 
work for at least six months. The solid line shows estimates for a dynamically evolving sample, where the estimate for month $\mathrm{t}$ includes only those who have not returned to work by month $\mathrm{t}^{24}$

Estimates for the full exhaustion sample show that household income falls by about 15 percent of its pre-separation level in the month following the end of UI benefits. Average incomes rebound thereafter - by month 5, they exceed their level while on UI, though they remain about 15 percent below their pre-job-separation level. The rebound reflects the return to work of some exhaustees in months two and thereafter. In our sample of still-jobless workers, there is much less rebound; the initial drop is similar, but incomes remain 30 percent below the pre-separation level through the end of our sample. This is our first piece of evidence that income components other than the exhaustee's own earnings contribute little to filling the hole left by the disappearance of UI benefits.

Figure 5 examines the evolution of different components of household income for the dynamic sample of ongoing nonemployment spells. UI payments drop from about 25 percent of pre-separation income to zero at exhaustion. There is no sign of an immediate response of either other household members' earnings or transfer payments. Each rises gradually in the months following UI exhaustion, but the cumulative magnitudes are quite small relative to the lost UI income. ${ }^{25}$ Transfer payments increase by about eight percent of pre-displacement income over the six months following exhaustion. We show below that this is driven by Social Security income and concentrated among older exhaustees; responses for those not able to draw on Social Security are much smaller. Panel D of the Figure shows the evolution of the household poverty

\footnotetext{
${ }^{24}$ As implied by our earlier discussion of Appendix Figure B1 (Section 4B), about 45 percent of our exhaustees remained nonemployed for at least 6 months after their UI benefits stopped.

${ }^{25}$ Note that the increase may reflect the dynamically evolving sample composition, as the population represented for, say, four months after the end of UI benefits is different from that represented at one month after benefit exhaustion.
} 
rate. Poverty rises immediately and dramatically following the loss of UI benefits, by about 15 percentage points.

Figures 4 and 5 show relatively consistent patterns during the periods preceding and following the loss of UI benefits. To pin down the quantitative effects, we turn to an examination of average outcomes over the period three months prior to and six months following the cessation of UI benefits. Table 4 has the same structure and underlying sample of nonemployed UI exhaustees as Table 3, but it focuses on the period surrounding UI exhaustion rather than the period surrounding the initial job separation. We compute pre-exhaustion and post-exhaustion means of each outcome, including in the latter only months during the nonemployment spell. That is, if an individual returns to work three months after exhaustion, her post-exhaustion mean is calculated as the average of her month +1 and month +2 observations. To reduce sample selection effects arising from differences in survival time, in averaging across individuals we weight individuals - and not observed months - equally.

Table 4 shows that when UI benefits expire households lose UI income equal to about one-quarter of pre-separation household income, or about one-third of their income just prior to UI exhaustion, roughly the mirror image of the increase following job loss. The drop in UI income is buffered somewhat by increases in other income sources. The main offsetting increase is in own earnings, amounting to a bit less than 10 percent of pre-separation income, or less than one-fifth of pre-separation own earnings. This is consistent with our definition of reemployment, which requires the individual to remain reemployed for at least four consecutive weeks so allows for earnings from transitory or intermittent jobs during an ongoing nonemployment spell. ${ }^{26}$

\footnotetext{
${ }^{26}$ While the results for other household member earnings and total income may be affected by changes in marital status, this influence appears limited. From two months prior to two months after exhaustion, less than 2 percent of our sample changes marital status (measured by presence of spouse in the household). Transitions into and out of marriage almost exactly offset, so the fraction married in our sample is
} 
Looking across other income sources, we see significant increases in SNAP benefits, other social assistance, and Social Security payments, but both the participation rate effects and dollar amounts are very small - the latter add up to less than one-tenth of the lost UI income. ${ }^{27}$ As a result, household income declines by 13 percent of its pre-separation level, on net, following UI exhaustion. This amounts to a decline of $\$ 522$ per month, on average. Family poverty rates rise by about 13 percentage points (on a base of 20 percent at the end of the UI spell). Appendix Table B1 shows that these patterns are largely unchanged when we restrict the sample to UI exhaustion spells for which time spent on UI is at least 75 percent of the legislative maximum in the state, where we are more confident of the exogeneity of measured UI exhaustion. One exception is own earnings, which as expected increase by somewhat less following exhaustion in this restricted sample due to our narrower measurement of true exhaustions. $^{28}$

Table 5 presents evidence on health-related outcomes, in particular receipt of public and private health insurance and self-reported work disability status, for our UI exhaustee sample during the periods surrounding job loss (Panel A) and UI exhaustion (Panel B). The structure is similar to Tables 3 and 4, respectively. Panel A shows that the fraction of our sample of eventual UI exhaustees covered by private health insurance falls by 18 percentage points shortly after job loss. This is partly offset by a nearly 7 percentage point increase in coverage through Medicaid,

essentially unchanged after UI exhaustion.

${ }^{27}$ Our findings regarding participation in other transfer programs are broadly consistent with the findings in U.S. GAO (2012), which uses a different sample and method of identifying exhaustees. UI benefits are commonly included as income for purposes of determining eligibility for means-tested transfer programs. However, any resulting delays in claiming such benefits are likely to be resolved within the six-month post-exhaustion timeframe for our analyses.

${ }^{28}$ These results are all based on unweighted analyses; Appendix Table B2 replicates the analysis with SIPP sample weights and shows that the results are not sensitive to the use or exclusion of weights. 
but the overall fraction lacking coverage increases substantially. ${ }^{29}$ Panel B shows no further decline in private coverage following UI exhaustion but a further rise in coverage via Medicaid. Of the 45 percent of exhaustees who maintain private insurance, a relatively high proportion (about two-thirds) are married and probably obtain insurance through their spouses. We examine outcome heterogeneity by marital status below.

Table 5 also lists the prevalence of self-reported work-limiting and work-preventing disabilities; the latter is conditioned on the respondent reporting a work-limiting disability, so the total prevalence is reflected in the work-limiting category. Panel A shows that work-limiting and work-preventing disabilities rise by about 4.5 and 4 percentage points, respectively, following job separation. A likely partial explanation is that some of the workers in our sample lose their jobs due to the onset of a disability. Interestingly, disability rates rise again following UI exhaustion (Panel B). The prevalence of work-limiting disabilities in our sample of exhaustees rises by another three percentage points at the time of UI exhaustion. The rise in work-preventing disabilities is even larger, at 4.5 percentage points, nearly doubling the pre-exhaustion prevalence and implying that some respondents switch from reporting work-limiting to workpreventing disabilities. Because these data are self-reported, it is impossible to know whether they represent real changes in health status or changes in reporting, perhaps influenced by a decision to apply for disability benefits. It is worth noting, however, that there is no direct incentive to misreport one's health status on the SIPP. This pattern of rising self-reported disability may imply a subsequent increase in DI applications. ${ }^{30}$

\footnotetext{
${ }^{29}$ For an earlier period, Gruber and Madrian (1997) document substantial declines in health insurance coverage among job separators in general.

${ }^{30}$ Direct analysis of DI applications would require matching our SIPP records with administrative data (as in Lindner 2011 and Rutledge 2012). Using such data, Couch et al. (2013) found that extended jobless spells experienced by prime-age men around the time of the 1980-82 recessions were associated with significantly higher likelihoods of DI benefit receipt 20 years later.
} 
A potential methodological concern with the pre-post comparisons in Tables 4 and 5 is that the comparison groups are not fully balanced because individuals drop out of the post sample when they become reemployed. Our use of averages only over pre-reemployment months is meant to address this, but would not do so perfectly if outcomes were related to the time since job separation. Even pure calendar time effects - e.g., rising disability rates - could appear as exhaustion effects in these analyses. In Appendix C, we describe and present results from an event study analysis that accounts both for the changing composition of the sample and possible time patterns in our outcomes that are unrelated to individual UI exhaustion. Results are similar to those from the simpler analyses in Tables 4 and 5.

Declines in household income are of relatively little concern if UI exhaustee households have substantial wealth and assets that can be used to substitute for lost income during their prolonged nonemployment spells. As discussed in Section 4B, prior to job separation the households of eventual UI exhaustees have net worth and liquid financial wealth that is somewhat lower than other UI recipients and not substantially different from job separators in general.

We expand on these earlier tabulations by examining changes in household net worth and liquid financial wealth for our UI exhaustee sample before, during, and after their nonemployment spells. ${ }^{31,32}$ Following our approach in previous tables of comparing income changes to pre-separation household income, Figure 6 translates these household wealth measures into equivalent months of pre-separation household income, with net worth displayed

\footnotetext{
${ }^{31}$ We limit this sample to UI exhaustees for whom we can match wealth data from the topical modules to all three sub-periods relative to their nonemployment spells. This reduces the sample size substantially because the relevant topical modules were administered annually and not at all after 2011 (most of the loss of observations is post spell, after 2011). The results are similar, however, when we include all observations with wealth data for each separate sample sub-period.

${ }^{32}$ Gruber (2001) examines wealth holdings of the unemployed in detail, using earlier SIPP panels.
} 
in Panel A and liquid financial wealth in Panel B. Panel A shows that about 35-40 percent of UI exhaustee households have total net worth that equals less than one month of pre-separation income, with the fraction rising slightly across the before, during, and after spell periods. On the other hand, the fraction with net worth equal to at least six months of household income also rises slightly across the three periods, to about 50 percent in the post period. As discussed earlier, for many respondents net worth largely consists of home equity. Home price indices indicate rising home prices throughout the 2001 panel and for the second half of the 2008 panel (from 2012 onward), with rough stability from mid-2009 through late-2012. ${ }^{33}$ The long-term unemployed may have faced difficulties accessing their home equity to finance current consumption, however.

The tabulations for liquid wealth in Panel B indicate smaller short-term financial cushions. Over 60 percent of UI exhaustee households have liquid wealth equal to one month or less of pre-separation income, with the fraction rising slightly across the three periods. Only about 15 percent have liquid wealth equal to six or more months of pre-separation income. Moreover, as noted in Section 4B, our liquid wealth measure is not adjusted for credit card balances and other unsecured debt. The median household in our exhaustee sample has unsecured debt in the range of about $\$ 2,000$ (inflation adjusted as in Table 1) prior to the nonemployment spell, with declines generally evident during and after the spell. This suggests limited reliance on credit cards to finance consumption during the spell, and more speculatively that households typically do not have access to additional credit of this form while unemployed.

\footnotetext{
${ }^{33}$ See, e.g., https://fred.stlouisfed.org/graph/?g=deG5.
} 


\section{B. Sub-sample analyses}

To further probe the UI exhaustion effects, Tables 6 and 7 repeat the primary analyses of changes in income components and health-related outcomes from Tables 4 and 5B for subsamples of UI exhaustees. To conserve space, we list only the average difference between the period before and after the end of UI benefits (corresponding to the results in column 3 in Tables 4 and 5B). We provide four breakdowns: by age (greater than or less than 50); household composition (married or single, with or without children); three income groups (defined by terciles of household income prior to job loss); and period (2001 panel vs. 2008 panel).

The differences in results across age groups, household composition, and income are modest and generally not surprising. Individuals over age 50 see smaller increases in own earnings and larger increases in Social Security benefits and self-reported disability following UI exhaustion than do younger individuals. ${ }^{34}$ Comparing across household composition groups, single parents see the largest proportional income drop and largest increase in poverty, primarily because their incomes are initially low. For groups defined by pre-separation income tercile, the loss of UI benefits has the smallest proportional effect on total household income in the highest income group, as expected. Also as expected, the lowest income group sees the largest increase in income from social welfare program participation (including Medicaid), although the increase is not statistically significant in some cases; they also see a large and statistically significant increase in self-reported disability status. Perhaps surprisingly, the increase in poverty rates is similar across the three income groups.

\footnotetext{
${ }^{34}$ Additional age breakdowns not reported show that the results regarding Social Security receipt are primarily driven by individuals age 62 and over, as expected given the normal age requirements associated with claiming Social Security benefits.
} 
The final two columns in Panel B of Tables 6 and 7 compare results between the 2001 and 2008 SIPP panels. The differences in results once again are modest. The proportional decline in income is larger in the 2008 panel, but the increase in poverty rates is very similar across the two panels. Exhaustees in the 2008 panel experience a larger increase in participation in social welfare programs, such as food stamps and other social assistance, but the associated income amounts are quite small. The increases in Medicaid recipiency and self-reported disability also are somewhat larger in the 2008 panel.

To summarize the results by sub-groups, they generally show that UI exhaustion is associated with especially adverse consequence for less advantaged groups. This includes single parents and households with low pre-separation income: the income hit is larger for them, and their higher take-up of alternative social benefits does little to offset it. A similar interpretation applies to the results for the 2008 SIPP panel versus the 2001 panel: the former recession was much more severe, and UI exhaustees in that period relied more on other social benefits and reported a larger increase in disability following the loss of UI.

\section{Conclusion}

Little is known about individuals who remain jobless for a prolonged period after their UI benefits are exhausted, in part because in normal times this is an unusual occurrence. During the Great Recession and its aftermath, however, the severity of long-term unemployment created large numbers of UI exhaustees, despite the historically unprecedented extensions of available benefits. Using panel data from the SIPP, we find that the characteristics of UI exhaustees during this period and in the early 2000s are broadly similar to the characteristics of other individuals 
who are unemployed due to a job loss but do not exhaust their benefits. Of course, UI exhaustees have longer nonemployment durations.

The loss of UI benefits is associated with substantial declines in income for the large fraction of UI exhaustees who remain nonemployed. Although participation in other safety net programs increases, these programs make up only a small share of the lost UI income. The incidence of poverty - measured post-transfer in our analyses - spikes. These patterns are most pronounced for less advantaged groups in our data, including single parents and households with initially low income.

Our results imply that UI benefits in general, and in particular extended benefits during our two SIPP sample frames of 2001-04 and 2008-12, function as an important element of the social safety net in the United States that is not duplicative of other programs (consistent with Bitler and Hoynes 2013). We find limited evidence for UI benefits operating as substitutes or complements with other programs, at least over the short timeframe that we examine (Inderbitzin, Staubli, and Zweimuller 2016). Given the large numbers of individuals who received extended benefits during 2008-12, and the subsequent large numbers who have exhausted them, these considerations loom especially large in recent years.

There are three significant caveats to our analysis, which suggest avenues for future research. First, we measure family income changes but not consumption. It is possible that families are able to draw on savings or loans from outside the immediate family to offset the impact of sharp income declines. While we cannot definitively reject this possibility, our analyses using supplemental SIPP data on assets and liabilities suggests that exhaustee households have very little wealth—outside of home equity and retirement funds — that can be used to sustain consumption during their nonemployment spells (consistent with Gruber 2001). 
Further direct analysis of wealth buffers and consumption losses could be informative on these points.

A second caveat is that our SIPP data and empirical methods are better suited for capturing high-frequency changes in income in the months immediately surrounding exhaustion than they are at identifying responses that happen months or years later. This may cause us to miss some program interaction effects, particularly with respect to programs with long and variable lags between eligibility and receipt (like Disability Insurance or the Earned Income Tax Credit). We expect that our estimates understate the medium-term effects of UI exhaustion on Social Security income and Medicaid recipiency as well, but we do a better job of capturing effects on receipt of food stamps and other cash transfer programs with relatively quick application processes. Further analyses that track UI exhaustees over a longer timeframe would be useful in this regard.

Finally, and related, the increase in self-reported work disability that occurs after UI exhaustion raises the possibility that some exhaustees may later file for and receive disability insurance payments. This has been an active topic for research, and the findings are far from definitive (see Lindner 2011, Lindner and Nichols 2012, Rutledge 2012, Mueller, Rothstein, and von Wachter 2016). Expansion of our analysis to a longer timeframe and perhaps incorporation of administrative data on disability program applications could shed significant light on these issues. Only about one-sixth of our sample reports work-related disabilities after exhaustion, however, suggesting that disability insurance will not offset lost UI income for most exhaustees. 


\section{References}

Autor, David, Nicole Maestas, Kathleen Mullen, and Alexander Strand. 2011 "Does Delay Cause Decay? The Effect of Administrative Decision Time on the Labor Force Participation and Earnings of Disability Applicants." MRRC Working Paper \#2011-258, September.

Baily, Martin N. 1978. "Some Aspects of Optimal Unemployment Insurance." Journal of Public Economics 10 (December): 379-402.

Bitler, Marianne, and Hilary Hoynes. 2016. "The More Things Change, the More They Stay the Same? The Safety Net and Poverty in the Great Recession." Journal of Labor Economics 34(S1): S403-S444

Card, David, Raj Chetty, and Andrea Weber. 2007. "The Spike at Benefit Exhaustion: Leaving the Unemployment System or Starting a New Job?" American Economic Review, Papers and Proceedings 97: 113-118.

Card, David and Philip B. Levine. 2000. "Extended Benefits and the Duration of UI Spells: Evidence from the New Jersey Extended Benefit Program." Journal of Public Economics 78(1-2): 107-138.

Chetty, Raj. 2006. "A General Formula for the Optimal Level of Social Insurance." Journal of Public Economics 90: 1879-1901.

Chetty, Raj. 2008. "Moral Hazard versus Liquidity and Optimal Unemployment Insurance." Journal of Political Economy 116(2): 173-234.

Couch, Kenneth A., and Dana W. Placzek. 2010. "Earnings Losses of Displaced Workers Revisited." American Economic Review 100(1, March): 572-89.

Couch, Kenneth A., Gayle Reznik, Christopher R. Tamborini, and Howard Iams. 2013. "Economic and Health Implications of Long-Term Unemployment: Earnings, Disability Benefits, and Mortality." Research in Labor Economics 38: 259-305.

Cullen, Julie Berry, and Jonathan Gruber. 2000. "Does Unemployment Insurance Crowd Out Spousal Labor Supply?” Journal of Labor Economics 18 (3, July): 546-72.

Eggleston, Jonathan S., and Mark A. Klee. 2015. "Reassessing Wealth Data Quality in the Survey of Income and Program Participation.” SIPP Working Paper Number 274, U.S. Census Bureau. February.

Farber, Henry S., and Robert G. Valletta. 2015. "Do Extended Unemployment Benefits Lengthen Unemployment Spells? Evidence from Recent Cycles in the U.S. Labor Market." Journal of Human Resources 50(4, Fall): 873-909. 
Farber, Henry S., Jesse Rothstein, and Robert G. Valletta. 2015. "The Effect of Extended Unemployment Insurance Benefits: Evidence from the 2012-2013 Phase-Out." American Economic Review: Papers \& Proceedings 105(5): 171-176

Ganong, Peter, and Jeffrey B. Liebman. 2013. "The Decline, Rebound, and Further Rise in SNAP Enrollment: Disentangling Business Cycle Fluctuations and Policy Changes." NBER Working Paper No. 19363, August. Cambridge, MA: National Bureau of Economic Research.

Gruber, Jonathan. 1997. "The Consumption Smoothing Benefits of Unemployment Insurance.” American Economic Review 87(1): 192-205.

Gruber, Jonathan. 2001. "The Wealth of the Unemployed." Industrial and Labor Relations Review 55(1, October): 79-94.

Gruber, Jonathan, and Brigitte C. Madrian. 1997. "Employment Separation and Health Insurance Coverage." Journal of Public Economics 66(3, Dec.): 349-82

Ham, John C., Xianghong Li, and Lara Shore-Sheppard. 2009. "Seam Bias, Multiple-State, Multiple-Spell Duration Models and the Employment Dynamics of Disadvantaged Women.” NBER Working Paper No. 15151, July. Cambridge, MA: National Bureau of Economic Research.

Inderbitzin, Lukas, Stefan Staubli, and Josef Zweimüller. 2016. "Extended Unemployment Benefits and Early Retirement: Program Complementarity and Program Substitution." American Economic Journal: Economic Policy 8(1, Feb.): 253-288.

Katz, Lawrence F., and Bruce D. Meyer. 1990. "The Impact of the Potential Duration of Unemployment Benefits on the Duration of Unemployment." Journal of Public Economics 41(1): 45-72.

Kolsrud, Jonas, Camille Landais, Peter Nilsson, and Johannes Spinnewijn. 2016. "The Optimal Timing of Unemployment Benefits: Theory and Evidence from Sweden." Working paper, London School of Economics, June.

Kroft, Kory, and Matthew J. Notowidigdo. 2016. "Should Unemployment Insurance Vary with the Unemployment Rate? Theory and Evidence." Review of Economic Studies 83(3, July): 1092-1124.

Landais, Camille, Pascal Michaillat, and Emmanuel Saez. 2016. "A Macroeconomic Approach to Optimal Unemployment Insurance: Theory." Working Paper, August. Forthcoming in American Economic Journal: Economic Policy.

Lindner, Stephan. 2011. "How Does Unemployment Insurance Affect the Decision to Apply for Social Security Disability Insurance?” Working paper, Urban Institute. Washington, DC. 
Lindner, Stephan, and Austin Nichols. 2012. "The Impact of Temporary Assistance Programs on Disability Rolls and Re-Employment." Working Paper 2012-2. Chestnut Hill, MA: Center for Retirement Research at Boston College.

Meyer, Bruce D., Wallace K.C. Mok, and James X. Sullivan. 2015. “The Under-Reporting of Transfers in Household Surveys: Its Nature and Consequences.” Working paper, June (revised version of NBER Working Paper No. 15181, July 2009).

Moore, Jeffrey C. 2007. "Seam Bias in the 2004 SIPP Panel: Much Improved, but Much Bias Still Remains." Working paper, US Census Bureau, December.

Mueller, Andreas I., Jesse Rothstein, and Till M. von Wachter. 2016. "Unemployment Insurance and Disability Insurance in the Great Recession." Journal of Labor Economics 34: S445S475.

Needels, Karen, Walter Corson, and Walter Nicholson. 2001. "Left Out of the Boom Economy: UI Recipients in the Late 1990s.” Report, Mathematica Policy Research, October. Princeton, NJ.

Rothstein, Jesse. 2011. "Unemployment Insurance and Job Search in the Great Recession." Brookings Papers on Economic Activity, Fall: 143-210.

Rutledge, Matthew S. 2012. "The Impact of Unemployment Insurance Extensions on Disability Insurance Application and Allowance Rates.” Working Paper 2011-17, revised April 2012. Chestnut Hill, MA: Center for Retirement Research at Boston College.

Saporta-Eksten, Itay. 2014. "Job Loss, Consumption and Unemployment Insurance." Manuscript, Tel-Aviv University, October.

Schmieder, Johannes F., Till Von Wachter, and Stefan Bender. 2012. "The Effects of Extended Unemployment Insurance over the Business Cycle: Evidence from Regression Discontinuity Estimates over 20 Years.” Quarterly Journal of Economics 127: 701-52.

U.S. Congressional Budget Office. 2004. Family Income of Unemployment Insurance Recipients. Washington, DC: Congress of the United States. March.

U.S. Congressional Budget Office. 2012. Unemployment Insurance in the Wake of the Recent Recession. Washington, DC: Congress of the United States. November.

U.S. Government Accountability Office. 2012. "Unemployment Insurance: Economic Circumstances of Individuals Who Exhausted Benefits.” GAO-12-408. Washington, DC: February.

Valletta, Robert G. 2014. "Recent Extensions of U.S. Unemployment Benefits: Search Responses in Alternative Labor Market States." IZA Journal of Labor Policy 3 (Sept.): 125. 
Whittaker, Julie M. 2008. "Extending Unemployment Compensation Benefits During Recessions." Report RL34340, Congressional Research Service, December.

Whittaker, Julie M., and Katelin P. Isaacs. 2012. "Unemployment Insurance: Programs and Benefits." Report RL33362, Congressional Research Service, April. 
Figure 1: UI Benefit Duration and Recipiency, 2000-2013

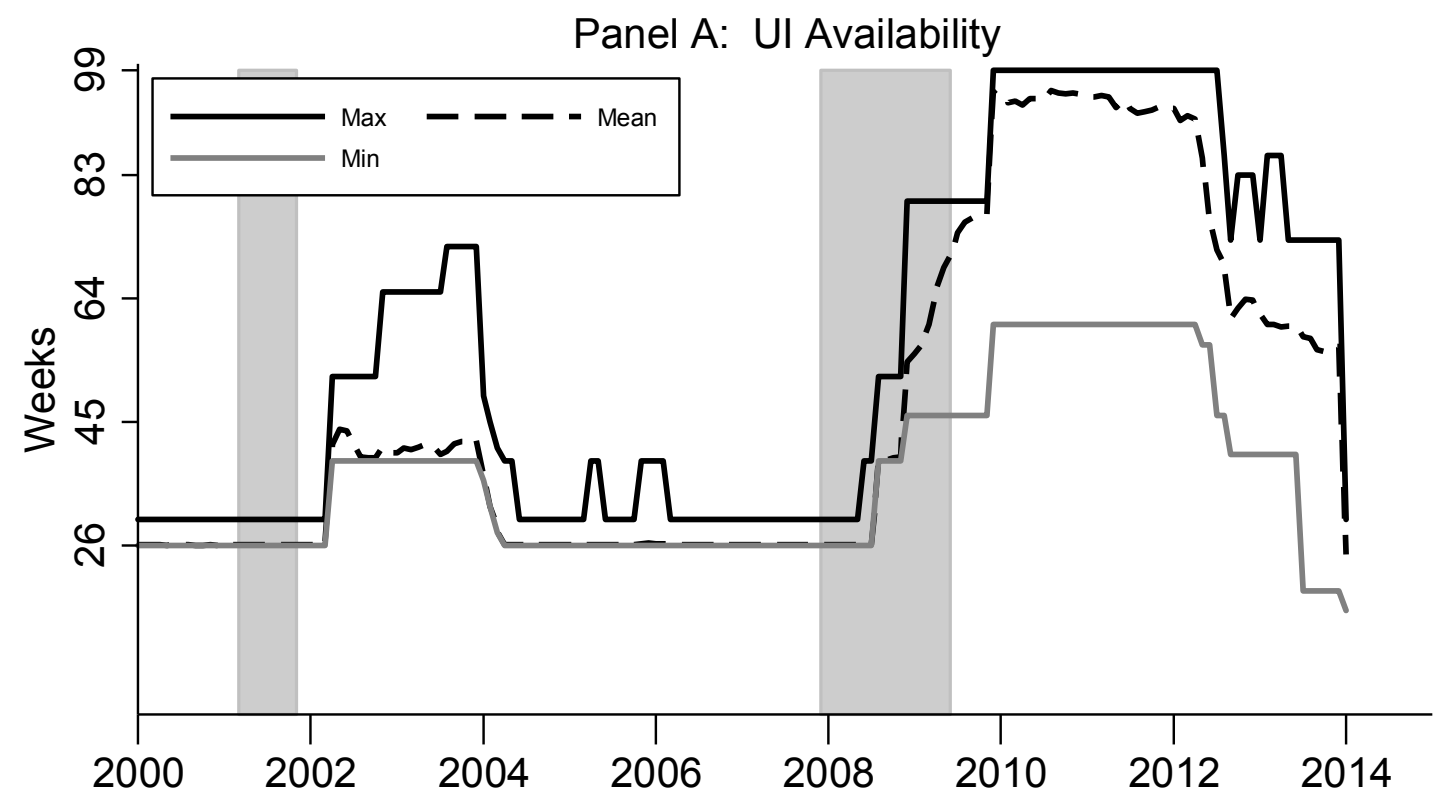

Note: Authors' calculations from U.S. DOL and BLS data. Minimum and maximum measured across states, average weighted by job losers in monthly CPS data. Temporary program suspensions (Apr, Jun/Jul, and Dec 2010) ignored. Gray areas denote NBER recession dates.

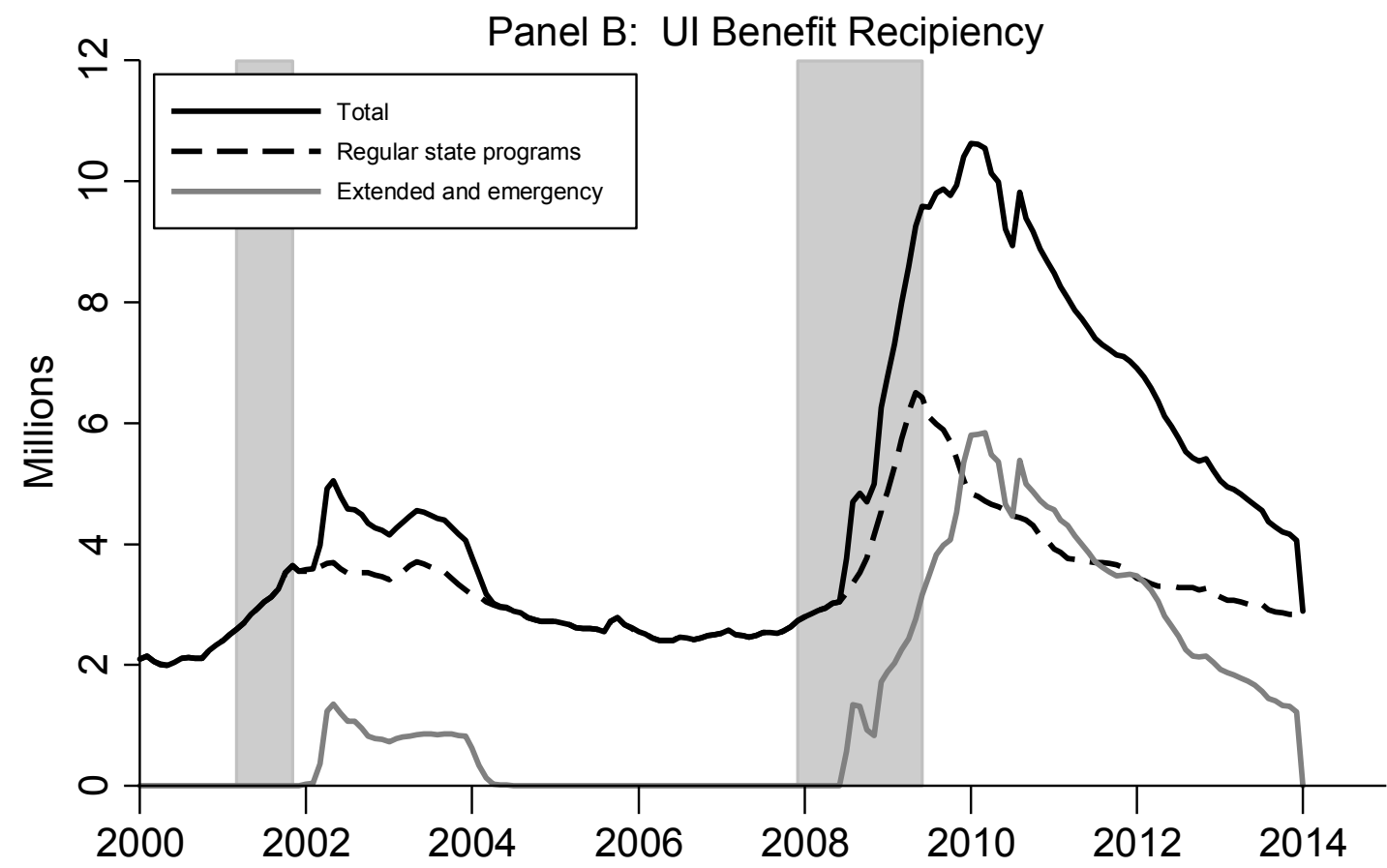

Note: From U.S. DOL (seasonally adjusted). Gray areas denote NBER recession dates. 


\section{Figure 2: Distribution of UI Benefit Duration UI exhaustee sample}
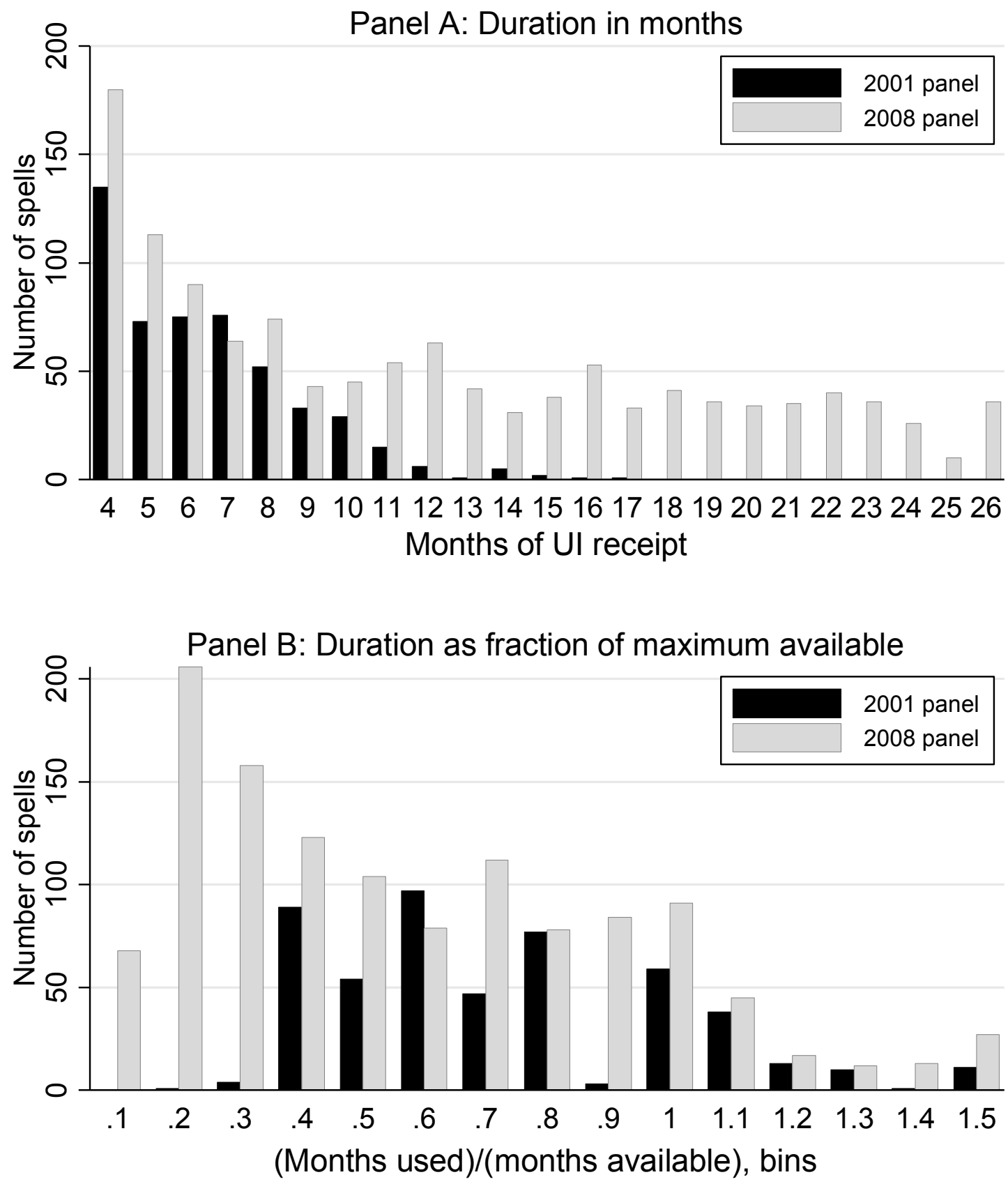

Note: Unweighted SIPP data. UI exhaustion sample consists of nonemployment spells following job loss in which UI was received for at least 4 months but no UI was received in the first two months following reemployment; see text for details. UI duration is the number of calendar months with positive UI income, and is censored at 26 months in panel A. Maximum available benefits are the number of weeks available in the month the last UI payment was received, divided by (52/12). 
Figure 3: Household Income (ratio to pre-separation average)

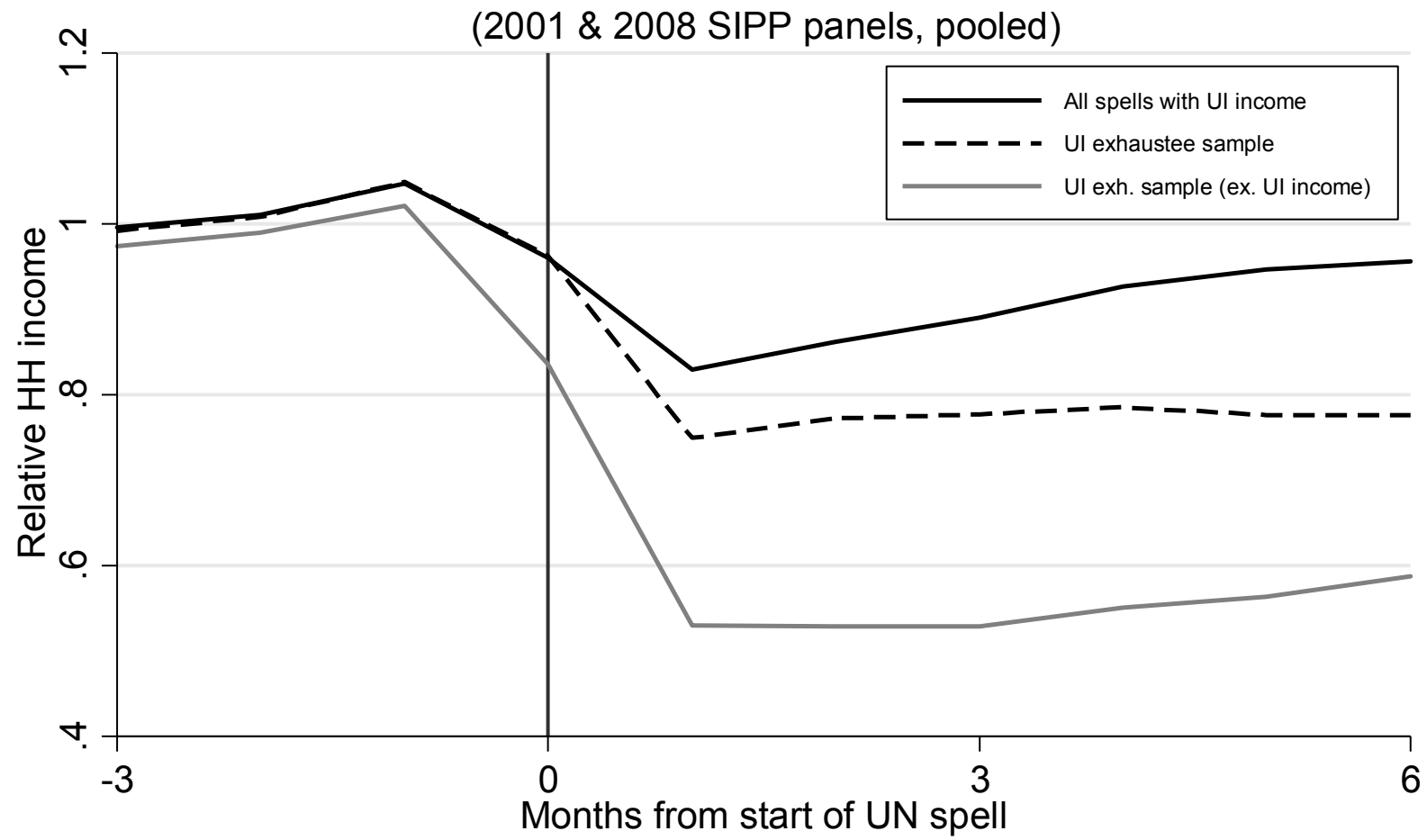

Note: Samples restricted to UI recipients. Job separation occurs in month 0 . UI exhaustion sample is spells for which UI benefits stop prior to job finding. Unweighted data. Each spell is treated as a distinct event. 
Figure 4: Household income (around UI exhaustion) 2001 \& 2008 panels; ratio to pre-separation average
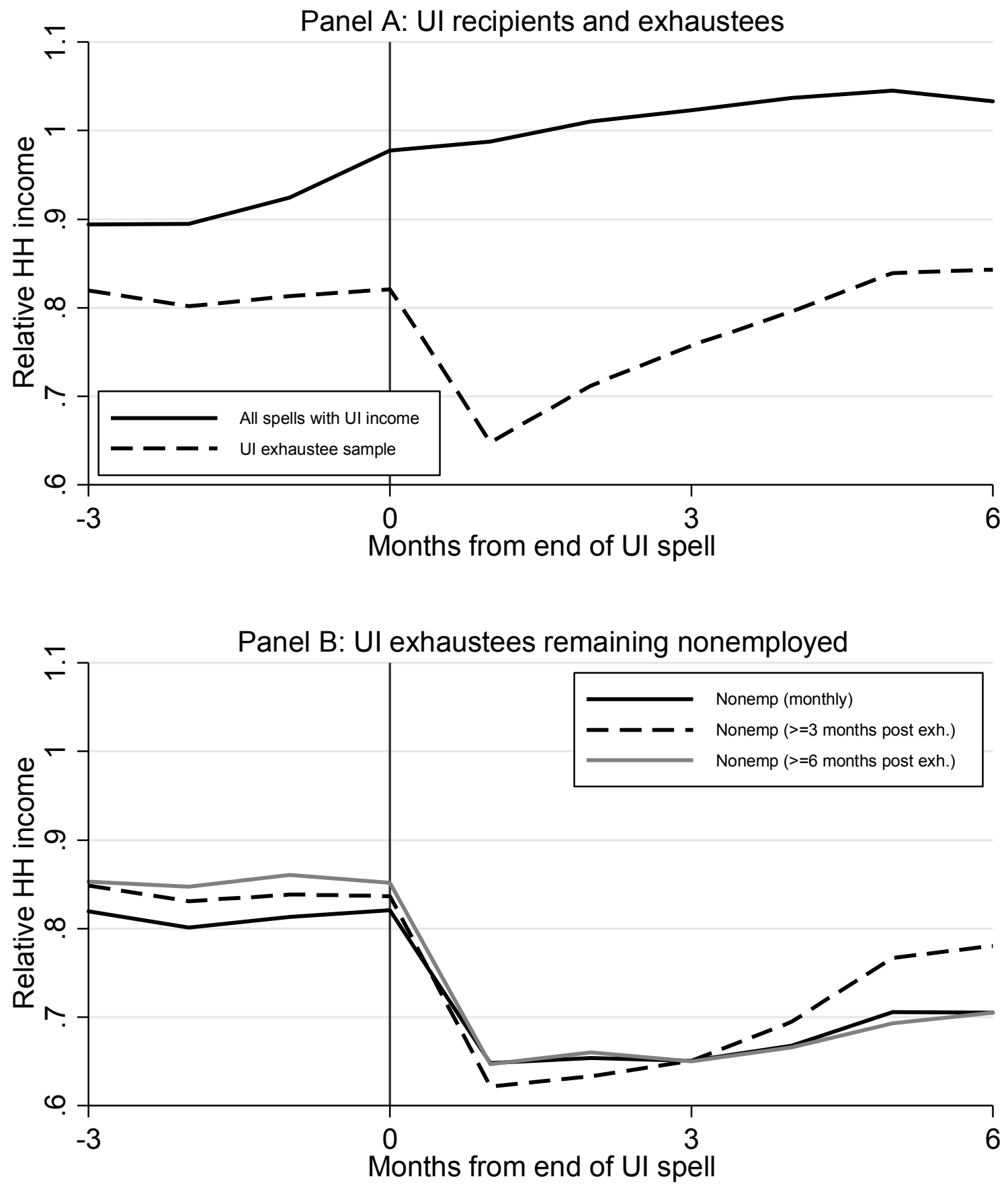

Note: Samples restricted to UI recipients. UI payments end in month 0. Panel A displays all UI recipient spells and those for whom benefits stop prior to job finding. Panel $B$ displays results separately for a those who are non-employed each month and for fixed samples of those who remain non-employed for at least 3 or 6 months after exhaustion. Each spell is treated as a distinct event. 
Figure 5: Household income components and poverty (around UI exhaustion)

Ratio to pre-separation average $\mathrm{HH}$ income (ex. poverty rate)
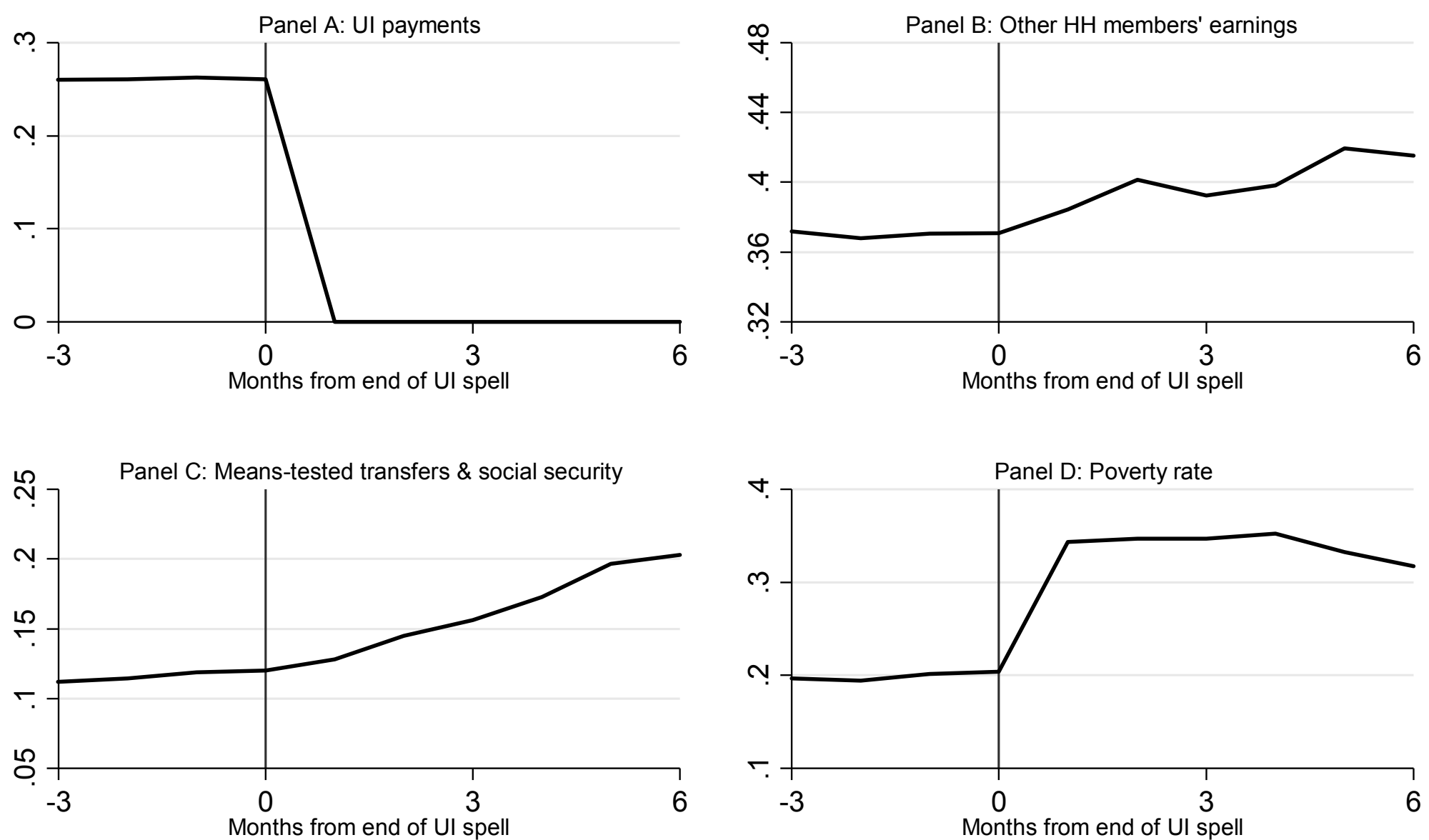

Note: See notes to Figure 4. For months $>0$, only ongoing non-employment spells are included. Vertical axis scale differs across panels. 


\section{Figure 6: Household Wealth, UI Exhaustees}

\section{Measured relative to pre-separation household income, in months}

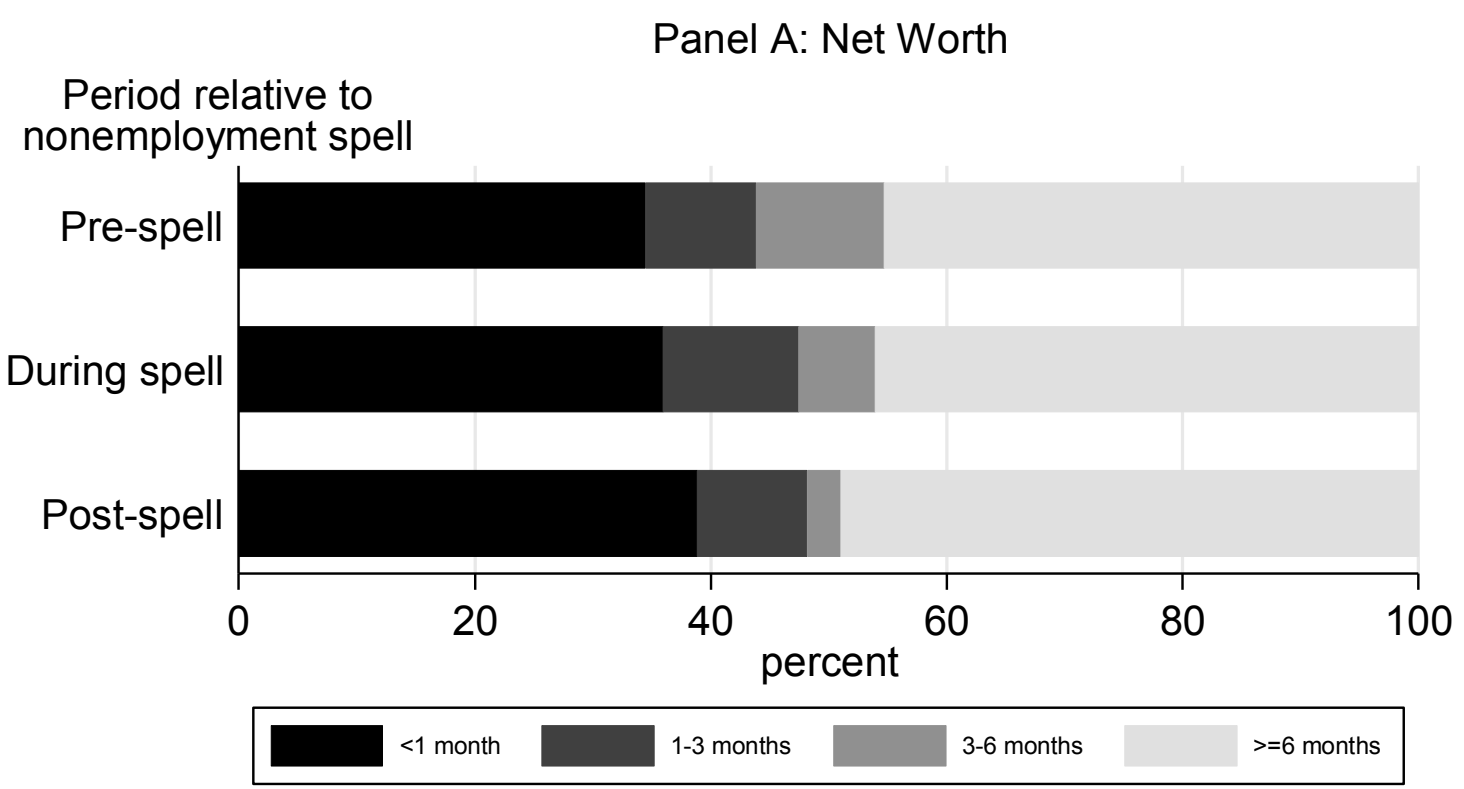

Panel B: Liquid Financial Wealth

Period relative to

nonemployment spell

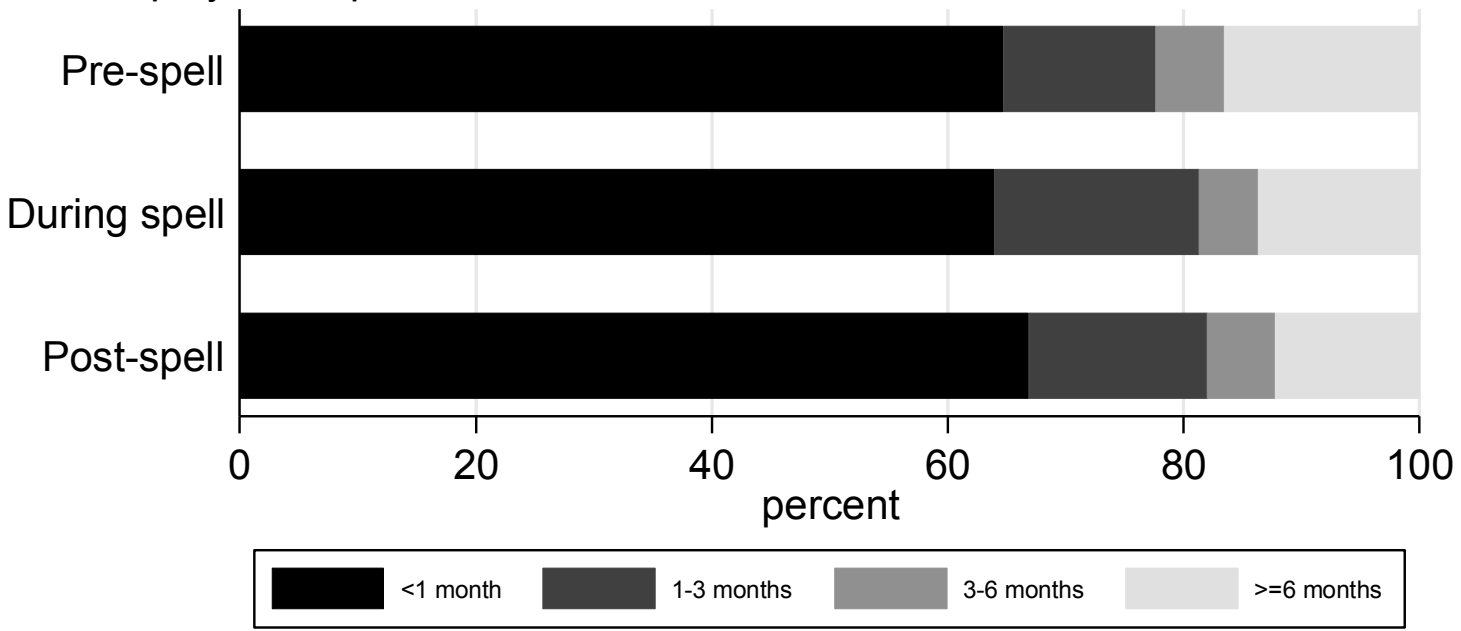

Note: Displays percent of observations with household wealth equal to the sum of pre-separation household income over the indicated number of months. Net worth defined as the sum of selfreported household asset values and equity (real estate, business, vehicles, other) less total unsecured debt (credit cards, other). Liquid financial wealth excludes equity in own home, vehicles, and business, plus retirement accounts; not reduced by unsecured debt. Pre and post periods extend 13 months before and after the date of job loss. Sample restricted to nonemployment spells for which wealth data is available in all three periods $(\mathrm{N}=139)$. 
Table 1: Descriptive Statistics, SIPP Nonemployment Spells (2001 and 2008 Panels) (spells completed or censored in final panel month)

(1) (2)

(3)

(4)

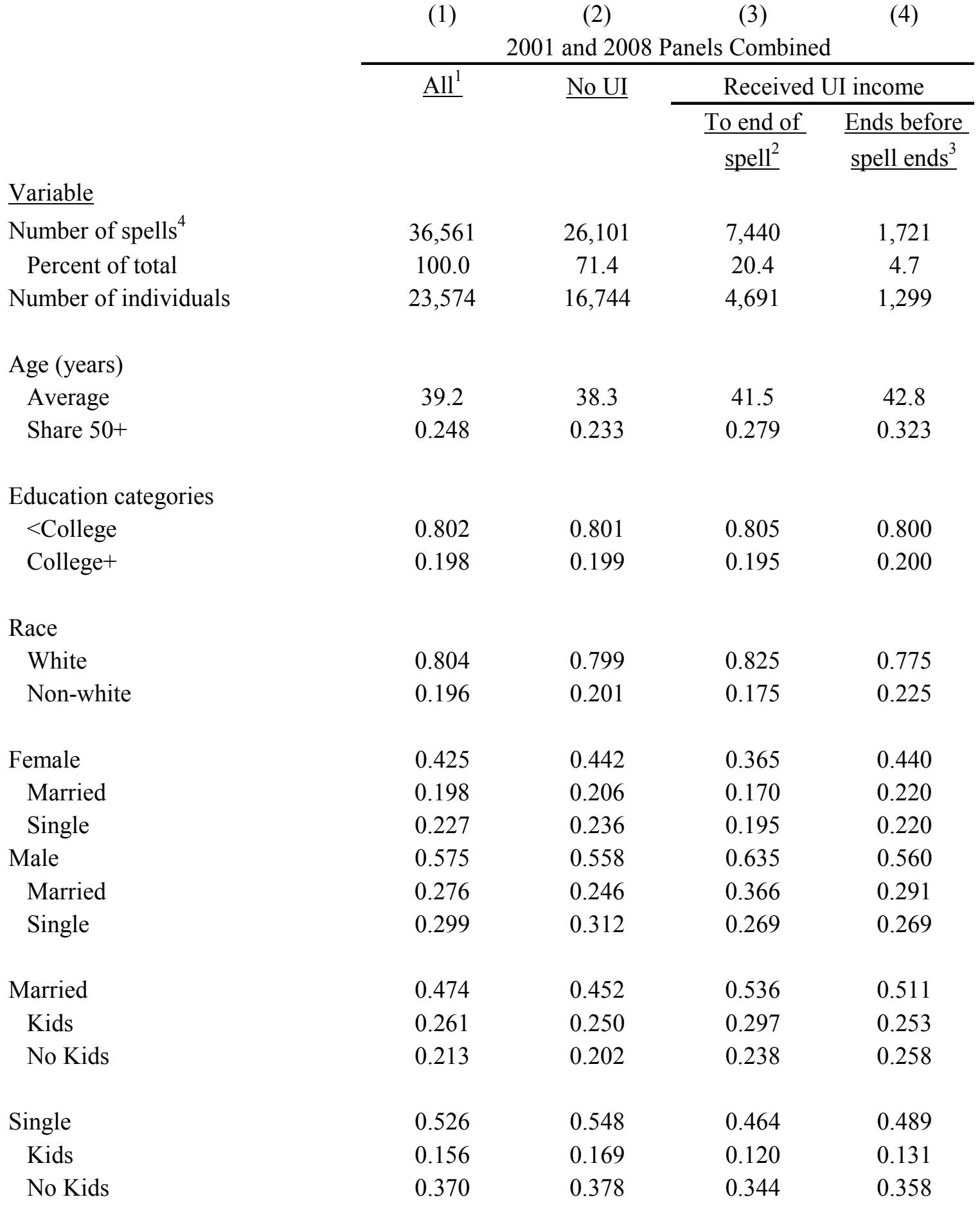

(Continued) 
Table 1 (continued)

Variable

(1) (2)

2001 and 2008 Panels Combined

\begin{tabular}{lll} 
All $^{1}$ & No UI & \multicolumn{2}{c}{ Received UI income } \\
\cline { 3 - 3 } & $\frac{\text { To end of }}{\text { spell }^{2}}$ & $\frac{\text { Ends before }}{\text { spell ends }}$
\end{tabular}

Income amounts (before job separation; means, inflation adjusted) ${ }^{5}$

Monthly UI (UI $>0$ only)

Monthly earnings ${ }^{6}$

Monthly HH total income

2,337

1,163

1,151

5,785

2,013

3,185

3,119

Household in poverty

0.231

0.251

6,127

6,149

Household wealth (before job separation; medians, inflation adjusted) ${ }^{5,7}$

Net worth

33,090

31,346

38,928

33,195

Liquid financial wealth

1,348

1,189

1,830

1,549

Observation count (wealth data)

20,188

14,276

4,168

983

Footnotes:

(1) All nonemployment spells initiated with at least one week of reported unemployment (active job search).

(2) Includes all spells in which UI income is still being received at the end of the spell or again within two months after spell ends.

(3) Includes only spells in which UI is received for four or more months.

(4) Columns 2-4 do not sum to column 1 due to a small share of unclassified observations (spells with short-term UI receipt followed by non-employment without UI).

(5) Dollar amounts expressed in sample end terms (Nov. 2013) using the GDP PCE deflator.

(6) Monthly earnings not available for all spells due to restriction that earnings are computed 24 months prior to (after) spell start (end).

(7) Net worth defined as the sum of self-reported household asset values and equity (real estate, business, vehicles, other) less total unsecured debt (credit cards, other). Liquid financial wealth excludes equity in own home, vehicles, and business, plus retirement accounts; not reduced by unsecured debt. Based on available spell observations with data from the SIPP assets and liabilities topical modules (up to 13 months prior to the spell start date).

Note: Calculations use SIPP cross-section weights (except unweighted "number" counts). Weight value generally corresponds to final month of the nonemployment spell, except weighted counts, which are based on the average final weight across all spell months. 
Table 2: Descriptive Statistics, SIPP Nonemployment Spells (2001 and 2008 Panels)

(completed or censored in final panel month)

(1) (2) (3) $\quad$ (4)

2001 Panel

\begin{tabular}{llll} 
All & 2001 Panel & \\
\cline { 3 - 4 } & No UI & $\frac{\text { Received UI income }}{\frac{\text { To end of }}{\text { spell }^{2}}}$ & $\frac{\text { Ends before }}{\text { spell ends }^{3}}$
\end{tabular}

Variable

Number of spells ${ }^{4}$

Percent of total

Weighted number

Number of individuals

Weighted number

$\begin{array}{cccc}11,377 & 8,284 & 2,097 & 504 \\ 100.0 & 72.8 & 18.4 & 4.4 \\ 46,919,455 & 33,945,393 & 8,748,818 & 2,131,105 \\ 8,124 & 5,916 & 1,430 & 414 \\ 33,473,622 & 24,167,998 & 6,001,962 & 1,743,253\end{array}$

(5)

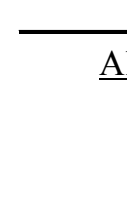

(6) 2008 Panel

\begin{tabular}{cccc} 
All $^{1}$ & No UI & \multicolumn{2}{c}{ Received UI income } \\
\cline { 3 - 5 } & & $\frac{\text { To end of }}{\text { spell }^{2}}$ & $\underline{\text { Ends before }^{\text {spell ends }}}$ \\
& & & \\
& & & \\
25,184 & 17,817 & 5,343 & 1,217 \\
100.0 & 70.7 & 21.2 & 4.8 \\
$94,321,698$ & $66,946,151$ & $19,800,138$ & $4,624,651$ \\
15,450 & 10,828 & 3,261 & 885 \\
$57,358,457$ & $40,142,657$ & $12,110,970$ & $3,350,687$
\end{tabular}

Duration of

nonemployment spell

\begin{tabular}{lcccccccc} 
Average & 16.1 & 13.4 & 14.1 & 56.9 & 24.8 & 18.8 & 24.7 & 101.3 \\
Share $<27$ weeks & 0.821 & 0.867 & 0.849 & 0.096 & 0.747 & 0.821 & 0.675 & 0.056 \\
Share 27-52 weeks & 0.117 & 0.086 & 0.135 & 0.464 & 0.126 & 0.099 & 0.190 & 0.209 \\
Share 53-99 weeks & 0.045 & 0.034 & 0.015 & 0.310 & 0.072 & 0.043 & 0.116 & 0.295 \\
$\quad$ Share $>99$ weeks & 0.016 & 0.012 & 0.001 & 0.130 & 0.056 & 0.038 & 0.019 & 0.440 \\
& & & & & & & & \\
Exit routes & & & & & & & & \\
$\quad$ Exit to employment & 0.803 & 0.821 & 0.797 & 0.569 & 0.792 & 0.813 & 0.783 & 0.546 \\
$\quad$ Censored & 0.197 & 0.179 & 0.203 & 0.431 & 0.208 & 0.187 & 0.217 & 0.454 \\
\hline
\end{tabular}

Footnotes:

(1) All nonemployment spells initiated with at least one week of reported unemployment (active job search).

(2) Includes all spells in which UI income is still being received at the end of the spell or again within two months after the spell ends.

(3) Includes only spells in which UI is received for four or more months.

(4) Columns 2-4 (6-8) do not sum to column 1 (5) due to a small share of unclassified observations (spells with short-term UI receipt followed by non-employment without UI).

Note: Calculations use SIPP cross-section weights (except unweighted "number" counts). Weight value generally corresponds to final month of nonemployment spell, except weighted counts, which are based on the average final weight across all spell months. 
Table 3. Household income before and after job separation

(UI exhaustee sample; 2001 and 2008 panels pooled)

(1)

$$
(2)
$$

(4)

$(5)$

(6)

\begin{tabular}{|c|c|c|c|c|c|c|}
\hline & \multicolumn{3}{|c|}{$\begin{array}{l}\text { Amounts (relative to pre-job } \\
\text { loss household income) }\end{array}$} & \multicolumn{3}{|c|}{$\begin{array}{l}\text { Any income (0-1; sample } \\
\text { fractions listed) }\end{array}$} \\
\hline & Pre & Post & Diff & Pre & Post & Diff \\
\hline \multirow[t]{2}{*}{ Household income (\$/month) } & 5,198 & 3,700 & $-1,498$ & -- & -- & -- \\
\hline & {$[3,423]$} & {$[3,000]$} & (93) & -- & -- & -- \\
\hline \multicolumn{7}{|l|}{ Income components } \\
\hline \multirow[t]{2}{*}{ Total } & 1.000 & 0.769 & -0.231 & -- & -- & -- \\
\hline & {$[0.000]$} & {$[0.563]$} & $(0.020)$ & -- & -- & -- \\
\hline \multirow[t]{2}{*}{ Own earnings } & 0.569 & 0.033 & -0.536 & 0.553 & 0.028 & -0.525 \\
\hline & {$[0.304]$} & {$[0.150]$} & $(0.012)$ & [0.309] & {$[0.166]$} & $(0.016)$ \\
\hline \multirow[t]{2}{*}{ Other HH member earnings } & 0.302 & 0.363 & 0.061 & 0.303 & 0.381 & 0.078 \\
\hline & [0.299] & {$[0.481]$} & $(0.015)$ & {$[0.303]$} & {$[0.534]$} & $(0.022)$ \\
\hline \multirow[t]{2}{*}{ UI } & 0.019 & 0.227 & 0.208 & 0.024 & 0.234 & 0.211 \\
\hline & {$[0.078]$} & {$[0.224]$} & $(0.008)$ & [0.089] & {$[0.229]$} & $(0.010)$ \\
\hline \multirow[t]{2}{*}{ SNAP } & 0.019 & 0.028 & 0.009 & 0.022 & 0.031 & 0.009 \\
\hline & {$[0.075]$} & [0.092] & $(0.002)$ & {$[0.081]$} & [0.099] & $(0.002)$ \\
\hline \multirow[t]{2}{*}{ Other social assistance } & 0.011 & 0.014 & 0.004 & 0.010 & 0.015 & 0.005 \\
\hline & {$[0.053]$} & {$[0.066]$} & $(0.002)$ & {$[0.052]$} & {$[0.070]$} & $(0.002)$ \\
\hline \multirow[t]{2}{*}{ Social Security } & 0.046 & 0.059 & 0.013 & 0.049 & 0.065 & 0.015 \\
\hline & {$[0.121]$} & {$[0.150]$} & $(0.003)$ & {$[0.126]$} & {$[0.152]$} & $(0.004)$ \\
\hline \multirow[t]{2}{*}{ Household in poverty } & -- & -- & -- & 0.078 & 0.220 & 0.142 \\
\hline & -- & -- & -- & {$[0.242]$} & {$[0.362]$} & $(0.012)$ \\
\hline
\end{tabular}

Notes: "Pre" columns report average values and standard deviations (in brackets) over the three months prior to the month in which job separation occurred. "Post" columns report average values over the period beginning the month after job separation and ending 6 months later or in the last month of the nonemployment spell, whichever comes first. "Diff" column reports the difference in means and the standard error (in parentheses) of this difference. Relative income measures divide monthly income by source by average household income in the period 2-4 months prior to the initial job loss. Households for which this average is below $\$ 500$ are set to missing; ratios are censored at [0,10]. $\mathrm{N}=466$ spells in 2001 panel, 1,149 spells in 2008 panel (sample from columns 4 and 8 in Table 2, less observations with missing values of average household income). Differences that are statistically significant at the $5 \%$ level are bolded. 
Table 4. Household income before and after the end of UI payments (UI exhaustee sample; 2001 and 2008 panels pooled)

\begin{tabular}{|c|c|c|c|c|c|c|}
\hline & $(1)$ & $(2)$ & (3) & $(4)$ & $(5)$ & $(6)$ \\
\hline & \multicolumn{3}{|c|}{$\begin{array}{l}\text { Amounts (relative to pre-job } \\
\text { loss household income) }\end{array}$} & \multicolumn{3}{|c|}{$\begin{array}{l}\text { Any income (0-1; sample } \\
\text { fractions listed) }\end{array}$} \\
\hline & Pre & Post & Diff & Pre & Post & Diff \\
\hline \multirow[t]{2}{*}{ Household income (\$/month) } & 3,795 & 3,273 & -522 & -- & -- & -- \\
\hline & {$[3,056]$} & {$[3,138]$} & $(72)$ & -- & -- & -- \\
\hline \multicolumn{7}{|l|}{ Income components } \\
\hline \multirow[t]{2}{*}{ Total } & 0.811 & 0.683 & -0.129 & -- & -- & -- \\
\hline & {$[0.616]$} & {$[0.697]$} & $(0.020)$ & -- & -- & -- \\
\hline \multirow[t]{2}{*}{ Own earnings } & 0.019 & 0.104 & 0.084 & 0.059 & 0.283 & 0.224 \\
\hline & {$[0.131]$} & {$[0.365]$} & $(0.012)$ & {$[0.237]$} & {$[0.451]$} & $(0.017)$ \\
\hline \multirow[t]{2}{*}{ Other HH member earnings } & 0.370 & 0.386 & 0.016 & 0.605 & 0.623 & 0.018 \\
\hline & {$[0.516]$} & {$[0.563]$} & $(0.013)$ & [0.489] & {$[0.485]$} & $(0.011)$ \\
\hline \multirow[t]{2}{*}{ UI } & 0.261 & 0.000 & -0.261 & 0.981 & 0.000 & -0.981 \\
\hline & {$[0.239]$} & {$[0.000]$} & $(0.008)$ & {$[0.137]$} & {$[0.000]$} & $(0.005)$ \\
\hline \multirow[t]{2}{*}{ SNAP } & 0.029 & 0.032 & 0.003 & 0.199 & 0.228 & 0.030 \\
\hline & {$[0.094]$} & {$[0.101]$} & $(0.002)$ & [0.399] & {$[0.420]$} & $(0.010)$ \\
\hline \multirow[t]{2}{*}{ Other social assistance } & 0.016 & 0.021 & 0.005 & 0.082 & 0.104 & 0.022 \\
\hline & {$[0.078]$} & [0.089] & $(0.002)$ & {$[0.275]$} & {$[0.305]$} & $(0.008)$ \\
\hline \multirow[t]{2}{*}{ Social Security } & 0.070 & 0.085 & 0.014 & 0.215 & 0.253 & 0.038 \\
\hline & {$[0.181]$} & {$[0.202]$} & $(0.004)$ & {$[0.411]$} & {$[0.435]$} & $(0.008)$ \\
\hline \multirow[t]{2}{*}{ Household in poverty } & -- & -- & -- & 0.195 & 0.324 & 0.129 \\
\hline & -- & -- & -- & {$[0.376]$} & {$[0.436]$} & $(0.015)$ \\
\hline
\end{tabular}

Notes: "Pre" columns report average values and standard deviations (in brackets) over the three months prior to the last month in which UI income was received. "Post" columns report average values over the period beginning the month after the last month of UI receipt and ending 6 months later or in the last month of the nonemployment spell, whichever comes first. "Diff" column reports the difference in means and the standard error (in parentheses) of this difference. Relative income measures divide monthly income by source by average household income in the period 2-4 months prior to the initial job loss. Households for which this average is below $\$ 500$ are set to missing; ratios are censored at $[0,10]$. $\mathrm{N}=466$ spells in 2001 panel, 1,149 spells in 2008 panel (sample from columns 4 and 8 in Table 2, less observations with missing values of average household income). Differences that are statistically significant at the $5 \%$ level are bolded. 
Table 5. Health insurance and health conditions (UI exhaustee sample; 2001 and 2008 panels pooled)

Panel A: Around job separation

\begin{tabular}{lccc} 
& \multicolumn{1}{c}{$(1)$} & $(2)$ & $(3)$ \\
\hline & \multicolumn{2}{c}{ Incidence (0-1; sample fractions listed) } \\
\cline { 2 - 4 } Covered by Medicaid & Pre & Post & Diff \\
\cline { 2 - 4 } & 0.092 & 0.158 & $\mathbf{0 . 0 6 6}$ \\
Covered by private health insurance & 0.701 & 0.521 & $\mathbf{- 0 . 1 8 0}$ \\
& {$[0.458]$} & {$[0.500]$} & $(0.016)$ \\
Disability: work limiting & 0.096 & 0.142 & $\mathbf{0 . 0 4 6}$ \\
& {$[0.295]$} & {$[0.349]$} & $(0.010)$ \\
Disability: work preventing & 0.009 & 0.047 & $\mathbf{0 . 0 3 8}$ \\
(conditional on work limiting=1) & {$[0.097]$} & {$[0.212]$} & $(0.008)$ \\
\hline
\end{tabular}

Panel B: Around end of UI payments

\begin{tabular}{|c|c|c|c|}
\hline & (1) & (2) & (3) \\
\hline & \multicolumn{3}{|c|}{ Incidence (0-1; sample fractions listed) } \\
\hline & Pre & Post & Diff \\
\hline \multirow[t]{2}{*}{ Covered by Medicaid } & 0.128 & 0.163 & 0.035 \\
\hline & {$[0.334]$} & {$[0.369]$} & $(0.010)$ \\
\hline \multirow[t]{2}{*}{ Covered by private health insurance } & 0.430 & 0.449 & 0.019 \\
\hline & {$[0.495]$} & {$[0.498]$} & $(0.012)$ \\
\hline \multirow[t]{2}{*}{ Disability: work limiting } & 0.137 & 0.167 & $\mathbf{0 . 0 3 0}$ \\
\hline & {$[0.344]$} & {$[0.373]$} & $(0.010)$ \\
\hline \multirow{2}{*}{$\begin{array}{l}\text { Disability: work preventing } \\
\text { (conditional on work limiting=1) }\end{array}$} & 0.056 & 0.102 & 0.045 \\
\hline & {$[0.230]$} & {$[0.302]$} & $(0.009)$ \\
\hline
\end{tabular}

Notes: Sample, estimation, and pre/post differences defined as in Tables 3 and 4 (column 6). Standard deviations listed in brackets, standard errors in parentheses. Differences that are statistically significant at the $5 \%$ level are bolded. 
Table 6. Household income before and after the end of UI payments, BY SUBGROUP (UI exhaustees, 2001 and 2008 panels pooled; PRE/POST AMOUNT DIFFERENCES ONLY)

Panel A: Demographics

\begin{tabular}{|c|c|c|c|c|c|c|}
\hline & $(1)$ & $(2)$ & (3) & (4) & $(5)$ & $(6)$ \\
\hline & \multicolumn{2}{|c|}{ Age } & \multicolumn{4}{|c|}{ Household composition } \\
\hline & $\leq \mathbf{5 0}$ & $\underline{\mathbf{5 0}+}$ & $\frac{\text { Single (no }}{\text { kids) }}$ & $\frac{\text { Single (with }}{\text { kids) }}$ & $\frac{\text { Married }}{\text { (no kids) }}$ & $\begin{array}{l}\text { Married } \\
\text { (with kids) } \\
\end{array}$ \\
\hline Household income (\$/month) & $\begin{array}{l}\mathbf{- 5 2 2} \\
(93)\end{array}$ & $\begin{array}{l}\mathbf{- 5 2 4} \\
(106)\end{array}$ & $\begin{array}{l}\mathbf{- 5 9 6} \\
(107)\end{array}$ & $\begin{array}{l}-257 \\
(186)\end{array}$ & $\begin{array}{l}-468 \\
(143)\end{array}$ & $\begin{array}{l}-620 \\
(164)\end{array}$ \\
\hline \multicolumn{7}{|l|}{ Income components } \\
\hline Total & $\begin{array}{l}\mathbf{- 0 . 1 3 1} \\
(0.027)\end{array}$ & $\begin{array}{l}\mathbf{- 0 . 1 2 4} \\
(0.027)\end{array}$ & $\begin{array}{l}\mathbf{- 0 . 1 7 9} \\
(0.036)\end{array}$ & $\begin{array}{l}-0.084 \\
(0.072)\end{array}$ & $\begin{array}{c}\mathbf{- 0 . 0 9 1} \\
(0.029)\end{array}$ & $\begin{array}{l}\mathbf{- 0 . 1 2 1} \\
(0.038)\end{array}$ \\
\hline Own earnings & $\begin{array}{c}\mathbf{0 . 1 0 3} \\
(0.017)\end{array}$ & $\begin{array}{c}\mathbf{0 . 0 4 7} \\
(0.012)\end{array}$ & $\begin{array}{c}\mathbf{0 . 0 7 7} \\
(0.014)\end{array}$ & $\begin{array}{c}\mathbf{0 . 1 4 0} \\
(0.056)\end{array}$ & $\begin{array}{c}\mathbf{0 . 0 4 8} \\
(0.014)\end{array}$ & $\begin{array}{c}\mathbf{0 . 0 9 9} \\
(0.027)\end{array}$ \\
\hline Other $\mathrm{HH}$ member earnings & $\begin{array}{c}0.012 \\
(0.018)\end{array}$ & $\begin{array}{c}0.025 \\
(0.019)\end{array}$ & $\begin{array}{c}0.012 \\
(0.025)\end{array}$ & $\begin{array}{c}0.039 \\
(0.045)\end{array}$ & $\begin{array}{c}0.012 \\
(0.018)\end{array}$ & $\begin{array}{c}0.014 \\
(0.025)\end{array}$ \\
\hline UI & $\begin{array}{l}\mathbf{- 0 . 2 6 5} \\
(0.010)\end{array}$ & $\begin{array}{l}-\mathbf{- 0 . 2 5 3} \\
(0.015)\end{array}$ & $\begin{array}{l}\mathbf{- 0 . 2 9 6} \\
(0.016)\end{array}$ & $\begin{array}{l}\mathbf{- 0 . 3 0 4} \\
(0.026)\end{array}$ & $\begin{array}{l}\mathbf{- 0 . 1 9 5} \\
(0.013)\end{array}$ & $\begin{array}{l}\mathbf{- 0 . 2 5 4} \\
(0.015)\end{array}$ \\
\hline SNAP & $\begin{array}{c}0.004 \\
(0.002)\end{array}$ & $\begin{array}{c}0.002 \\
(0.002)\end{array}$ & $\begin{array}{c}\mathbf{0 . 0 0 6} \\
(0.003)\end{array}$ & $\begin{array}{c}0.005 \\
(0.006)\end{array}$ & $\begin{array}{c}0.000 \\
(0.001)\end{array}$ & $\begin{array}{c}0.001 \\
(0.004)\end{array}$ \\
\hline Other social assistance & $\begin{array}{c}0.004 \\
(0.003)\end{array}$ & $\begin{array}{c}0.006 \\
(0.003)\end{array}$ & $\begin{array}{c}\mathbf{0 . 0 1 0} \\
(0.004)\end{array}$ & $\begin{array}{l}-0.003 \\
(0.008)\end{array}$ & $\begin{array}{c}0.002 \\
(0.003)\end{array}$ & $\begin{array}{c}0.005 \\
(0.004)\end{array}$ \\
\hline Social Security & $\begin{array}{c}0.004 \\
(0.005)\end{array}$ & $\begin{array}{c}\mathbf{0 . 0 3 4} \\
(0.008)\end{array}$ & $\begin{array}{c}0.015 \\
(0.008)\end{array}$ & $\begin{array}{c}0.016 \\
(0.017)\end{array}$ & $\begin{array}{c}\mathbf{0 . 0 2 2} \\
(0.007)\end{array}$ & $\begin{array}{c}0.005 \\
(0.006)\end{array}$ \\
\hline Household in poverty & $\begin{array}{c}\mathbf{0 . 1 3 1} \\
(0.018)\end{array}$ & $\begin{array}{c}\mathbf{0 . 1 2 4} \\
(0.024)\end{array}$ & $\begin{array}{c}\mathbf{0 . 1 9 6} \\
(0.026)\end{array}$ & $\begin{array}{c}\mathbf{0 . 1 1 1} \\
(0.045)\end{array}$ & $\begin{array}{c}\mathbf{0 . 0 6 2} \\
(0.023)\end{array}$ & $\begin{array}{c}\mathbf{0 . 1 1 3} \\
(0.028)\end{array}$ \\
\hline Observation count & 1074 & 541 & 566 & 228 & 402 & 419 \\
\hline
\end{tabular}

Panel B: Household income and SIPP panel

\begin{tabular}{|c|c|c|c|c|c|}
\hline & $(1)$ & $(2)$ & (3) & (4) & $(5)$ \\
\hline & \multicolumn{3}{|c|}{ Household income } & \multicolumn{2}{|c|}{ SIPP panel } \\
\hline & $\underline{\text { Low }}$ & Medium & $\underline{\text { High }}$ & $\underline{2001}$ & $\underline{2008}$ \\
\hline \multirow[t]{2}{*}{ Household income (\$/month) } & -347 & -637 & -580 & -419 & -564 \\
\hline & $(95)$ & $(122)$ & $(150)$ & $(122)$ & (88) \\
\hline \multicolumn{6}{|l|}{ Income components } \\
\hline \multirow[t]{2}{*}{ Total } & -0.151 & -0.158 & -0.076 & -0.104 & -0.139 \\
\hline & $(0.052)$ & $(0.028)$ & $(0.017)$ & $(0.029)$ & $(0.026)$ \\
\hline \multirow[t]{2}{*}{ Own earnings } & 0.134 & 0.064 & 0.056 & 0.096 & 0.080 \\
\hline & $(0.031)$ & $(0.016)$ & $(0.011)$ & $(0.021)$ & $(0.015)$ \\
\hline \multirow[t]{2}{*}{ Other HH member earnings } & 0.047 & 0.013 & -0.011 & 0.024 & 0.013 \\
\hline & $(0.033)$ & $(0.018)$ & $(0.013)$ & $(0.018)$ & $(0.017)$ \\
\hline \multirow[t]{2}{*}{ UI } & -0.393 & -0.246 & -0.145 & -0.246 & -0.267 \\
\hline & $(0.019)$ & $(0.011)$ & $(0.006)$ & $(0.015)$ & $(0.010)$ \\
\hline \multirow[t]{2}{*}{ SNAP } & 0.006 & 0.003 & 0.001 & 0.001 & 0.004 \\
\hline & $(0.005)$ & $(0.001)$ & $(0.000)$ & $(0.003)$ & $(0.002)$ \\
\hline \multirow[t]{2}{*}{ Other social assistance } & 0.011 & 0.002 & 0.002 & 0.002 & 0.006 \\
\hline & $(0.006)$ & $(0.002)$ & $(0.001)$ & $(0.004)$ & $(0.003)$ \\
\hline \multirow[t]{2}{*}{ Social Security } & 0.021 & 0.013 & 0.008 & 0.007 & 0.017 \\
\hline & $(0.012)$ & $(0.005)$ & $(0.003)$ & $(0.005)$ & $(0.006)$ \\
\hline \multirow[t]{2}{*}{ Household in poverty } & 0.124 & 0.149 & 0.114 & 0.132 & 0.128 \\
\hline & $(0.031)$ & $(0.024)$ & $(0.020)$ & $(0.028)$ & $(0.017)$ \\
\hline Observation count & 533 & 550 & 532 & 466 & 1149 \\
\hline
\end{tabular}

Notes: Base sample, estimation, and pre/post differences defined as in Table 4 (column 3). Income groups defined by terciles of household income prior to job separation. Standard errors in parentheses. Differences that are statistically significant at the $5 \%$ level are bolded. 
Table 7. Health insurance and health conditions before and after the end of UI payments, BY SUBGROUP (2001 and 2008 panels pooled; PRE/POST AMOUNT DIFFERENCES ONLY)

Panel A: Demographics

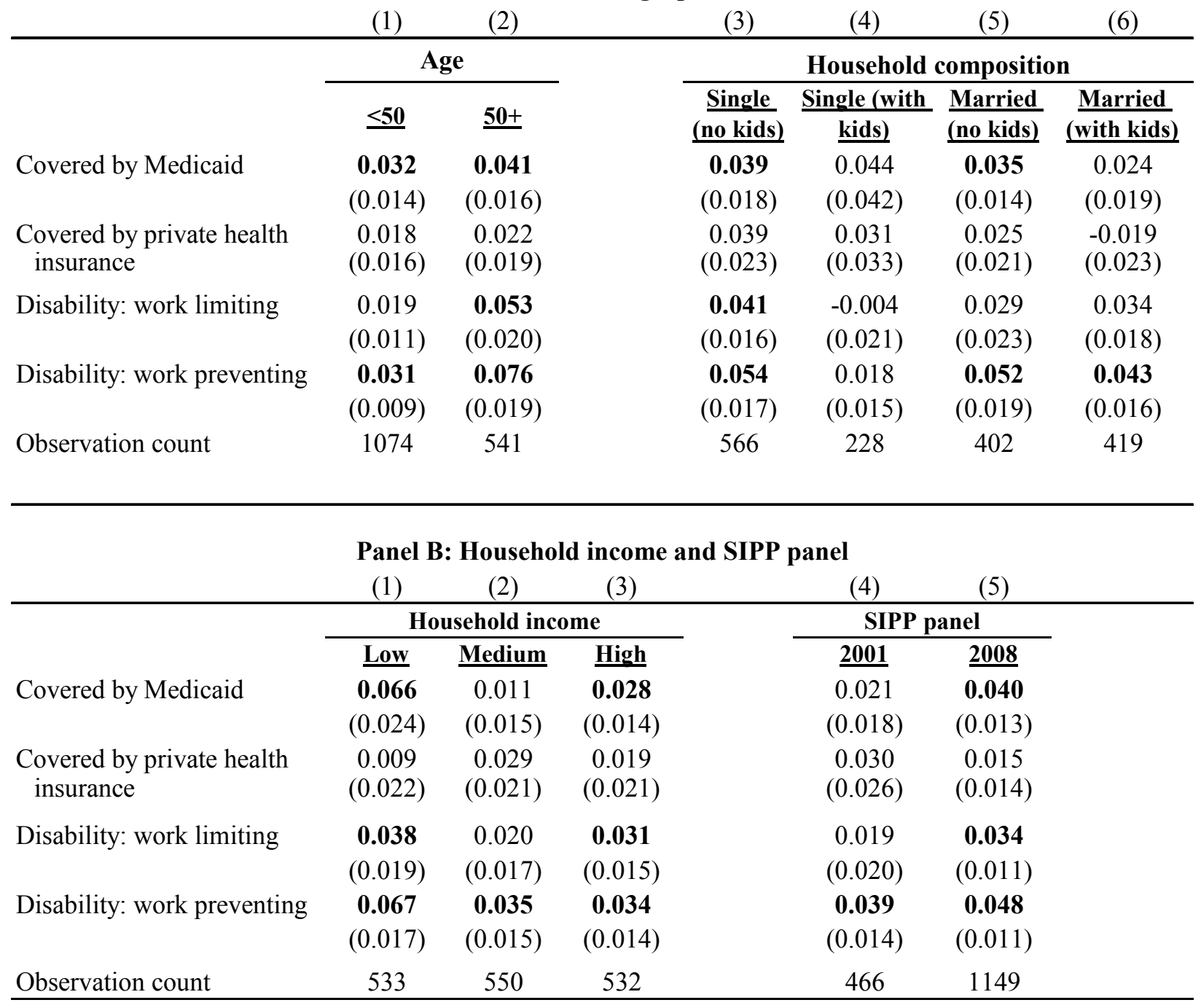

Notes: Base sample, estimation, and pre/post differences defined as in Table 5 (column 3). Income groups defined by terciles of household income prior to job separation. Standard errors in parentheses. Differences that are statistically significant at the $5 \%$ level are bolded. 


\section{Appendix A: Additional Details on the SIPP Extract Construction}

Age: We restrict the samples to individuals age 18 to 64 when they first entered the panel (wave 1 or later) and make the further restriction that individuals must always report being between age 18 and 69.

Qualifying nonemployment spells: We include only individuals who separate from a job and become unemployed after the beginning of the panel (or after entering the panel) and who are present in at least two consecutive waves.

Nonemployment duration: Labor force status is measured on a weekly basis.

Nonemployment spells begin with a job separation and increment weekly until a valid spell end is reached. The valid end of a nonemploment spell is identified by a string of four consecutive weeks in which the individual is employed (with the spell identified as ending in the first week of the 4-week string). Because we employ this 4-week forward-looking check, spells only increment if there are actually 4 weeks of observations to check (which eliminates the final panel month from the sample for all individuals).

Labor force transitions: For our sample of nonemployment spells initiated by unemployment, the two transitions we calculate separately and use for the spell survivor curves in Appendix Figure B1 are from unemployment to not in labor force (UN) and from unemployed to employed (UE). As above, a transition occurs only when an individual spends four consecutive weeks out of unemployment. A UE transition is judged to have occurred if the majority of labor force status values in the 4-week check period are employed. If there is a tie (e.g. with two weeks of employment and two weeks of nonparticipation), we look at the 5th week. If there is no 5th week (end of sample period) or the 5th week indicates that the person has returned to unemployment, then the transition is counted as an exit out of the labor force (UN). 
UI exhaustion: UI receipt is measured at a monthly frequency in the SIPP. We consider in our UI analyses only individuals who received UI for at least four months during their nonemployment spells. An exhaustee is a recipient who has at least one month of non-receipt preceding the end of the nonemployment spell.

Poverty measurement: To determine whether our sample individuals are in poverty, we compare their households' total monthly income (including money transfers, but excluding inkind transfers) to the corresponding Census Bureau poverty threshold (also expressed monthly, as provided in the SIPP data files based on each household's composition). 


\section{Appendix B: Supplemental Displays}

\section{Appendix Figure B1: Nonemployment/Unemployment Spell Survival Rates} Kaplan-Meier Estimates, by SIPP Panel
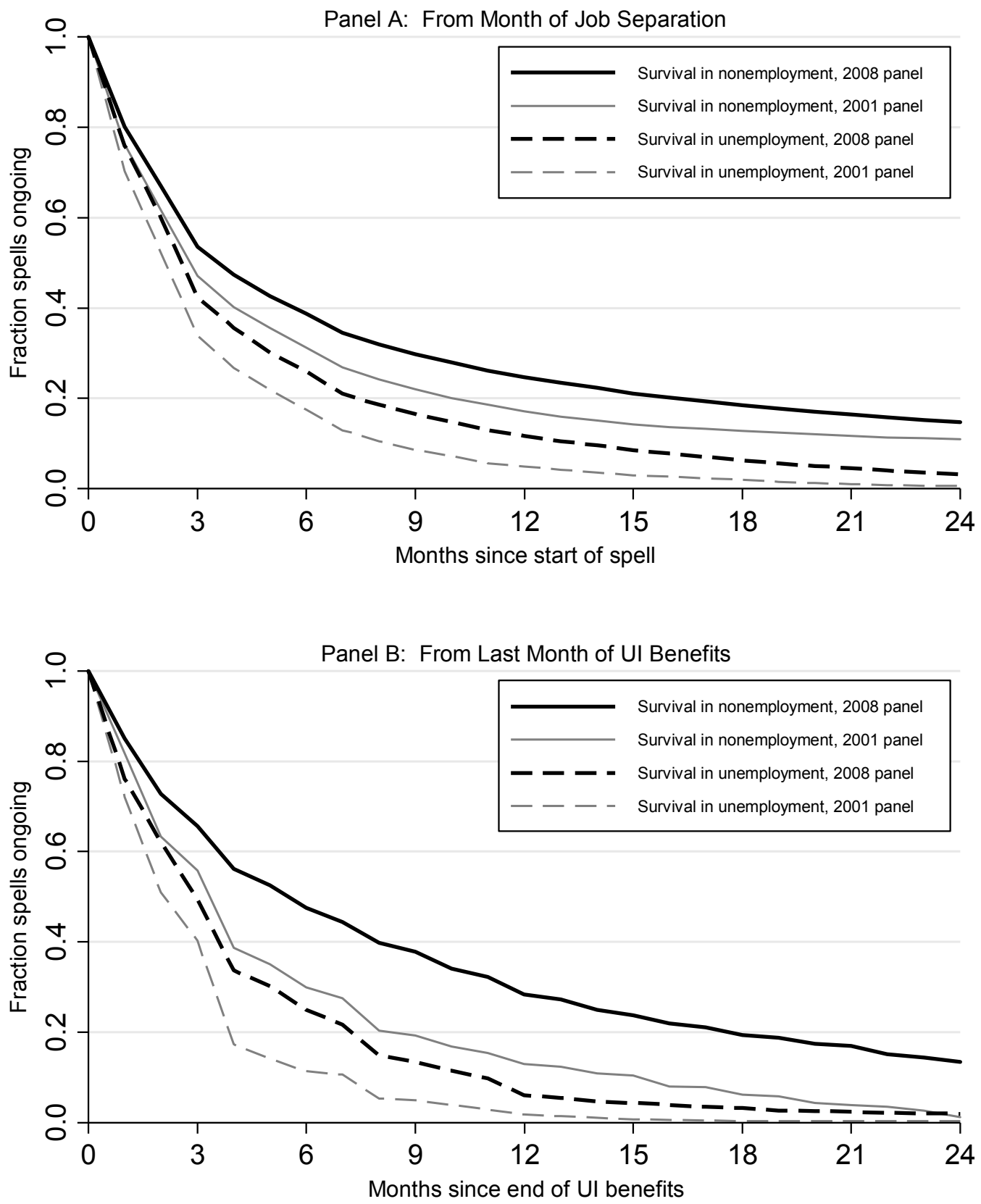

Note: Unweighted data. Base sample (Panel A) is unemployment spells initiated by job loss, duration of at least least one week; can convert to nonemployment spell. Each spell treated as a distinct event. Post-UI spells (Panel B) require at least 4 months of UI receipt. 
Table B1. Household income before and after the end of UI payments

(UI exhaustee sample; 2001 and 2008 panels pooled)

Sample with UI duration $>=75 \%$ of state maximum

\begin{tabular}{|c|c|c|c|c|c|c|}
\hline & (1) & $(2)$ & (3) & (4) & (5) & $(6)$ \\
\hline & \multicolumn{3}{|c|}{$\begin{array}{l}\text { Amounts (relative to pre-job } \\
\text { loss household income) }\end{array}$} & \multicolumn{3}{|c|}{$\begin{array}{l}\text { Any income (0-1; sample } \\
\text { fractions listed) }\end{array}$} \\
\hline & Pre & Post & Diff & Pre & Post & Diff \\
\hline \multirow{2}{*}{ Household income ( $\$ /$ month) } & 3,710 & 3,009 & -701 & -- & -- & -- \\
\hline & {$[3,001]$} & {$[2,937]$} & (94) & -- & -- & -- \\
\hline \multicolumn{7}{|l|}{ Income components } \\
\hline \multirow[t]{2}{*}{ Total } & 0.802 & 0.618 & -0.184 & -- & -- & -- \\
\hline & {$[0.643]$} & {$[0.586]$} & $(0.026)$ & -- & -- & -- \\
\hline \multirow[t]{2}{*}{ Own earnings } & 0.002 & 0.066 & 0.063 & 0.009 & 0.226 & 0.217 \\
\hline & {$[0.032]$} & [0.239] & $(0.014)$ & {$[0.097]$} & {$[0.419]$} & $(0.024)$ \\
\hline \multirow[t]{2}{*}{ Other HH member earnings } & 0.371 & 0.376 & 0.004 & 0.608 & 0.628 & 0.021 \\
\hline & {$[0.548]$} & {$[0.516]$} & $(0.015)$ & [0.489] & {$[0.484]$} & $(0.016)$ \\
\hline \multirow[t]{2}{*}{ UI } & 0.279 & 0.000 & -0.279 & 0.987 & 0.000 & -0.987 \\
\hline & {$[0.263]$} & {$[0.000]$} & $(0.015)$ & {$[0.112]$} & {$[0.000]$} & $(0.006)$ \\
\hline \multirow[t]{2}{*}{ SNAP } & 0.028 & 0.031 & 0.003 & 0.193 & 0.218 & 0.025 \\
\hline & {$[0.095]$} & {$[0.096]$} & $(0.003)$ & {$[0.395]$} & {$[0.413]$} & $(0.015)$ \\
\hline \multirow[t]{2}{*}{ Other social assistance } & 0.017 & 0.023 & 0.006 & 0.082 & 0.108 & 0.025 \\
\hline & {$[0.088]$} & [0.099] & $(0.003)$ & {$[0.275]$} & {$[0.310]$} & $(0.013)$ \\
\hline \multirow[t]{2}{*}{ Social Security } & 0.071 & 0.080 & 0.009 & 0.207 & 0.241 & 0.033 \\
\hline & {$[0.188]$} & {$[0.192]$} & $(0.005)$ & {$[0.406]$} & {$[0.428]$} & $(0.013)$ \\
\hline \multirow[t]{2}{*}{ Household in poverty } & -- & -- & -- & 0.179 & 0.346 & 0.167 \\
\hline & -- & -- & -- & {$[0.365]$} & [0.447] & $(0.024)$ \\
\hline
\end{tabular}

Notes: Sample and definitions as in Table 4 in the text (other than restriction noted in title above). Estimates weighted by the SIPP cross-section (monthly) weights, separately averaged over months in the pre and post periods. Differences that are statistically significant at the $5 \%$ level are bolded. 
Table B2. Household income before and after the end of UI payments (2001 and 2008 panels pooled)

With SIPP sample weights

(1)

\author{
(2)
}

(3)

(4)

$(5)$

(6)

\begin{tabular}{|c|c|c|c|c|c|c|}
\hline & \multicolumn{3}{|c|}{$\begin{array}{l}\text { Amounts (relative to pre-job } \\
\text { loss household income) }\end{array}$} & \multicolumn{3}{|c|}{$\begin{array}{l}\text { Any income (0-1; sample } \\
\text { fractions listed) }\end{array}$} \\
\hline & Pre & Post & Diff & Pre & Post & Diff \\
\hline \multirow{2}{*}{ Household income (\$/month) } & 3,787 & 3,240 & -540 & -- & -- & -- \\
\hline & {$[3,100]$} & {$[3,148]$} & (77) & -- & -- & -- \\
\hline \multicolumn{7}{|l|}{ Income components } \\
\hline \multirow[t]{2}{*}{ Total } & 0.792 & 0.661 & -0.132 & -- & -- & -- \\
\hline & {$[0.592]$} & {$[0.663]$} & $(0.020)$ & -- & -- & -- \\
\hline \multirow[t]{2}{*}{ Own earnings } & 0.017 & 0.106 & 0.088 & 0.057 & 0.284 & 0.227 \\
\hline & {$[0.124]$} & {$[0.362]$} & $(0.013)$ & {$[0.231]$} & {$[0.451]$} & $(0.018)$ \\
\hline \multirow[t]{2}{*}{ Other HH member earnings } & 0.369 & 0.380 & 0.011 & 0.607 & 0.622 & 0.016 \\
\hline & {$[0.498]$} & {$[0.551]$} & $(0.013)$ & {$[0.489]$} & {$[0.485]$} & $(0.011)$ \\
\hline \multirow[t]{2}{*}{ UI } & 0.257 & 0.000 & -0.257 & 0.979 & 0.000 & -0.979 \\
\hline & {$[0.231]$} & {$[0.000]$} & $(0.009)$ & {$[0.145]$} & {$[0.000]$} & $(0.006)$ \\
\hline \multirow[t]{2}{*}{ SNAP } & 0.027 & 0.031 & 0.003 & 0.190 & 0.216 & 0.022 \\
\hline & {$[0.091]$} & [0.099] & $(0.002)$ & {$[0.392]$} & {$[0.412]$} & $(0.010)$ \\
\hline \multirow[t]{2}{*}{ Other social assistance } & 0.016 & 0.021 & 0.005 & 0.079 & 0.103 & 0.021 \\
\hline & {$[0.078]$} & {$[0.089]$} & $(0.002)$ & {$[0.271]$} & {$[0.304]$} & $(0.009)$ \\
\hline \multirow[t]{2}{*}{ Social Security } & 0.063 & 0.075 & 0.012 & 0.198 & 0.234 & 0.036 \\
\hline & [0.169] & {$[0.185]$} & $(0.003)$ & {$[0.398]$} & {$[0.423]$} & $(0.008)$ \\
\hline \multirow[t]{2}{*}{ Household in poverty } & -- & -- & -- & 0.192 & 0.325 & 0.132 \\
\hline & -- & -- & -- & {$[0.374]$} & {$[0.438]$} & $(0.016)$ \\
\hline
\end{tabular}

Notes: Sample and definitions as in Table 4 in the text. Estimates weighted by the SIPP cross-section (monthly) weights, separately averaged over months in the pre and post periods. Differences that are statistically significant at the $5 \%$ level are bolded. 


\section{Appendix C: Event Study of UI Exhaustion}

\section{Framework}

To bolster and validate the largely descriptive results from the text, in this appendix we describe a more formal econometric analyses of income dynamics surrounding exhaustion (or other termination) of UI benefits. Our "event study" approach explicitly accounts for time trends and unemployment duration effects. We restrict the analyses to our sample of UI exhaustees (paralleling Table 4 in the text) and focus on a narrow timeframe around the last month in which UI benefits are received ( 3 months before and after, excluding the month prior to the last month of UI recipiency).

We estimate regressions of the following form:

$$
y_{i s d t}=\alpha_{i s}+\lambda_{d}+\beta_{t}+\varepsilon_{i s d t}
$$

In this equation, $i$ indexes individuals and $s$ indexes nonemployment spells (typically one per individual, but some have multiple spells in our data). The vector $\alpha$ represents fixed effects for each spell. The subscripts $d$ and $t$ refer to two time dimensions (in months): time since the beginning of the nonemployment spell $(d)$ and time since the end of the period of UI recipiency ( $t$, with negative numbers corresponding to months before UI exhaustion). Equation (1) includes complete vectors of fixed effects for each dimension, represented by $\lambda$ and $\beta$. The term $\varepsilon$ is a residual that is orthogonal to the explanatory variables by construction. The estimated standard errors are clustered by individual. We estimate this equation for a set of income-related dependent variables $y$, beginning with total household income, then considering income components one at a time, and ending with an indicator for family poverty. 
Our goal is to estimate the independent effect of UI exhaustion on the income-related outcomes, controlling for individual heterogeneity and nonemployment duration effects. The latter are captured through the $\beta_{t}$ coefficients. The controls for duration of nonemployment are included because UI exhaustion is more likely to occur at longer durations and duration itself may affect the other outcomes that we analyze, such as participation in other government income maintenance programs. The fixed effects for each spell account for observed and unobserved characteristics of individuals that affect their spell durations and may systematically relate to the other outcomes we examine. Together, the duration and spell controls will absorb a wide variety of unrelated determinants of outcomes that may correlate with the loss of UI benefits, making it likely that our estimated exhaustion effects reflect direct impacts of that loss rather than other individual characteristics and features of the economic environment.

Equation (1) does not include explicit controls for calendar time, though time-varying economic conditions are likely to be systematically related to UI exhaustion and the other outcomes that we examine. Importantly, spell effects $\left(\alpha_{i s}\right)$, unemployment duration effects $\left(\gamma_{d}\right)$, and calendar time effects are not separately and nonparametrically identified - this is a version of the age-time-cohort identification problem that is familiar from demographic studies. However, the effects of interest in our analysis are the exhaustion-time coefficients $\beta_{t}$. These are identified from variation across cohorts and across states for any particular cohort in the duration of UI benefits (relative to an excluded category; we normalize $\beta_{-1}=0$ ). Thus, in estimating versions of equation (1) that include parametric or nonparametric calendar time controls, we found that none of the substantive results regarding the effects of time since UI exhaustion effects differ from those presented here. 


\section{Event study regression results}

Table $\mathrm{C} 1$ contains the results for our primary event-study analysis of post-UI outcomes for our sample of UI exhaustees; it is structured similarly to Table 4 in the text. We estimate equation (1), normalizing $\beta_{-1}=0$ and setting $\beta_{t}=\beta_{-5}$ for $\mathrm{t}<-5$ and $\beta_{t}=\beta_{4}$ for $\mathrm{t}>4$. As above, the analysis is restricted to individuals who remain nonemployed after the loss of UI benefits, and monthly observations following the end of the nonemployment spell are dropped. We report averages of the pre-exhaustion period (corresponding to $\left.\left(\beta_{-4}+\beta_{-3}+\beta_{-2}\right) / 3\right)$ and the postexhaustion period $\left(\left(\beta_{1}+\beta_{2}+\beta_{3}\right) / 3\right)$, along with the difference between them.

The results with full event-study regression controls in Table C1 are quite similar to those without controls in Table 4 (focusing on the "Difference" results in columns 3 and 6). However, the statistical significance of a few of the smaller point estimates, such as the change in food stamp (SNAP) recipiency, is reduced. Household income falls by about 15 percent of its preseparation level in the month following the end of UI benefits. This loss is offset somewhat by increases in other income sources, mainly own earnings, with only trivial changes in non-UI transfer payments. Poverty rates increase by about 15 percentage points after UI exhaustion. 
Table C1. Event study of household income before and after the end of UI payments (UI exhaustee sample; 2001 and 2008 panels pooled) (coefficient estimates relative to last month of $\mathrm{UI}$ receipt $(t=0)$; standard errors in parentheses)

\begin{tabular}{|c|c|c|c|c|c|c|}
\hline & $(1)$ & $(2)$ & $(3)$ & $(4)$ & $(5)$ & $(6)$ \\
\hline & \multicolumn{3}{|c|}{$\begin{array}{c}\text { Amounts (relative to pre-job } \\
\text { loss household income) }\end{array}$} & \multicolumn{3}{|c|}{$\begin{array}{c}\text { Any income (0-1; sample } \\
\text { fractions listed) }\end{array}$} \\
\hline & $\begin{array}{c}\text { Average, } \\
\mathrm{t}=--4,-3,-2\end{array}$ & $\begin{array}{c}\text { Average, } \\
\mathrm{t}=+1,+2,+3\end{array}$ & Difference & $\begin{array}{c}\text { Average, } \\
\mathrm{t}=--4,-3,-2\end{array}$ & $\begin{array}{c}\text { Average, } \\
\mathrm{t}=+1,+2,+3\end{array}$ & Difference \\
\hline Household income (\$/month) & $\begin{array}{l}-33 \\
(44)\end{array}$ & $\begin{array}{l}-586 \\
(57)\end{array}$ & $\begin{array}{l}\mathbf{- 5 5 3} \\
(66)\end{array}$ & $\begin{array}{l}-- \\
--\end{array}$ & $\begin{array}{l}-- \\
--\end{array}$ & $\begin{array}{l}-- \\
--\end{array}$ \\
\hline Income components & & & & & & \\
\hline Total & $\begin{array}{l}-0.012 \\
(0.010)\end{array}$ & $\begin{array}{l}-0.170 \\
(0.016)\end{array}$ & $\begin{array}{l}\mathbf{- 0 . 1 5 8} \\
(0.018)\end{array}$ & $\begin{array}{l}-- \\
--\end{array}$ & $\begin{array}{l}-- \\
--\end{array}$ & $\begin{array}{l}-- \\
--\end{array}$ \\
\hline Own earnings & $\begin{array}{l}-0.025 \\
(0.007)\end{array}$ & $\begin{array}{c}0.054 \\
(0.007)\end{array}$ & $\begin{array}{c}\mathbf{0 . 0 7 9} \\
(0.007)\end{array}$ & $\begin{array}{l}-0.022 \\
(0.004)\end{array}$ & $\begin{array}{c}0.098 \\
(0.006)\end{array}$ & $\begin{array}{l}\mathbf{0 . 1 2 0} \\
(0.007)\end{array}$ \\
\hline Other HH member earnings & $\begin{array}{c}0.007 \\
(0.006)\end{array}$ & $\begin{array}{c}0.016 \\
(0.012)\end{array}$ & $\begin{array}{c}0.008 \\
(0.014)\end{array}$ & $\begin{array}{c}0.002 \\
(0.005)\end{array}$ & $\begin{array}{c}0.012 \\
(0.007)\end{array}$ & $\begin{array}{c}0.010 \\
(0.009)\end{array}$ \\
\hline UI & $\begin{array}{c}0.004 \\
(0.003)\end{array}$ & $\begin{array}{l}-0.266 \\
(0.007)\end{array}$ & $\begin{array}{l}-\mathbf{0 . 2 7 0} \\
(0.007)\end{array}$ & $\begin{array}{c}0.000 \\
(0.006)\end{array}$ & $\begin{array}{c}-0.963 \\
(0.006)\end{array}$ & $\begin{array}{l}\mathbf{- 0 . 9 6 4} \\
(0.007)\end{array}$ \\
\hline SNAP & $\begin{array}{c}0.000 \\
(0.001)\end{array}$ & $\begin{array}{c}0.002 \\
(0.001)\end{array}$ & $\begin{array}{c}0.002 \\
(0.002)\end{array}$ & $\begin{array}{c}0.001 \\
(0.004)\end{array}$ & $\begin{array}{c}0.008 \\
(0.007)\end{array}$ & $\begin{array}{c}0.008 \\
(0.008)\end{array}$ \\
\hline Other social assistance & $\begin{array}{c}0.000 \\
(0.001)\end{array}$ & $\begin{array}{c}0.004 \\
(0.002)\end{array}$ & $\begin{array}{c}0.003 \\
(0.002)\end{array}$ & $\begin{array}{c}-0.003 \\
(0.003)\end{array}$ & $\begin{array}{c}0.007 \\
(0.006)\end{array}$ & $\begin{array}{c}0.010 \\
(0.006)\end{array}$ \\
\hline Social Security & $\begin{array}{l}-0.004 \\
(0.003)\end{array}$ & $\begin{array}{c}0.004 \\
(0.004)\end{array}$ & $\begin{array}{c}0.007 \\
(0.004)\end{array}$ & $\begin{array}{l}-0.006 \\
(0.003)\end{array}$ & $\begin{array}{c}0.018 \\
(0.006)\end{array}$ & $\begin{array}{c}\mathbf{0 . 0 2 4} \\
(0.007)\end{array}$ \\
\hline Household in poverty & $\begin{array}{l}-- \\
--\end{array}$ & $\begin{array}{l}-- \\
--\end{array}$ & $\begin{array}{l}-- \\
--\end{array}$ & $\begin{array}{l}-0.005 \\
(0.006)\end{array}$ & $\begin{array}{c}0.144 \\
(0.012)\end{array}$ & $\begin{array}{c}\mathbf{0 . 1 4 9} \\
(0.012)\end{array}$ \\
\hline
\end{tabular}

Notes: Sample defined as in Table 4 in the text, except for a small number of missings for the complete regression sample periods ( $\mathrm{N}=1592$ spells; 460 in the 2001 panel and 1132 in the 2008 panel). See appendix text for description of event study regression model. Standard errors are clustered by individual. Estimates that are statistically significant at the $5 \%$ level are bolded. 